\title{
The water-sensitive city meets biodiversity: habitat services of rain water management measures in highly urbanized landscapes
}

\author{
Lauranne Pille $^{1}$ and Ina Säumel ${ }^{2}$
}

\begin{abstract}
Urban water managers face numerous challenges, including limited natural resources for maintenance of technical infrastructure, changing demography, and dramatic environmental degradation. Although the vision of the "water-sensitive city" helps to develop tools and strategies toward more sustainable urban water systems, it does not consider biodiversity effects. We therefore aimed to determine habitat provision or habitat services provided by important rainwater management measures (e.g., ponds, swales, rain gardens, green roofs, green walls, permeable pavement), and to highlight how specific design and management practices for such measures enhance urban biodiversity. There is evidence of habitat services provided by rainwater management measures. Nevertheless, the categorization of such measures as civil engineering structures and their related rules limit efforts to optimize the biodiversity friendliness of design and management. The main factors to provide enhanced and more sustainable habitats are shaping design and maintenance according to target species and favoring connectivity by integrating rainwater management measures into the urban bluegreen network. We find that strategic implementation of combinations of rainwater management measures into existing built-up areas allows greater multifunctionality of urban infrastructure. The "biodiversity-friendly and water-sensitive city" implies the efficient integration of ecological design measures in urban planning at building, neighborhood, and landscape scales.
\end{abstract}

Key Words: blue-green city; decentralized water infrastructure; low-impact development; stormwater management; sustainable urban water drainage; urban biodiversity

\section{INTRODUCTION}

Today, urban water managers are faced with many challenges, including complex demands of urbanization and environmental degradation, broad organizational and technological diversity within the water sector, and the uncertainty of global change (Maksimovic and Tejada-Guibert 2005). Current water infrastructure and management practice, however were established mainly in the previous century and are resistant to change (Brown and Farelly 2009, Apul 2010). Despite growing awareness of the need for strategic investment in long-term solutions for sustainable and adaptive urban water management, institutional inertia in water infrastructure systems is high, and sustainable urban water management is limited to a few demonstration projects (Brown and Farrelly 2009, Russo et al. 2014). To future-proof cities, there is a need for a shift from traditional water management toward more sustainable concepts (Lienert et al. 2006).

Centralized infrastructure currently addresses the symptoms of urban runoff issues, such as flood-prone heat islands, streambank erosion, and poor water quality, rather than addressing the root causes. In contrast, decentralized infrastructure can respond by integrating rainwater management (RWM) measures that favor the local infiltration of water at the city scale, allowing more terrestrial vegetation, better local climate regulation, and clean water supply, and reducing flooding events. Such measures also represent a cheaper alternative to centralized systems that involve the construction of important drainage systems (Montalto et al. 2013). Many of the new urban water frameworks that have emerged (Brown et al. 2008; see Fig. 1, stages I-VI) derive from the "water-cycle city" approach, which aims: (1) to shift from traditional centralized water management with large-scale systems and top-down governance models to decentralized water management based on small-scale systems with multilevel governance, and (2) to close water and energy loops involving rainwater, sewage, and graywater treatment, with specific adaptation of the water quality to appropriate uses. Two of these approaches are the "water-sensitive city" and the "blue-green city".

The water-sensitive city approach extends the water-cycle city approach by including normative values of a hydro-social contract with regard to environment repair and protection, security of supply, flood control, public health, amenity, livability, and economic sustainability (Brown et al. 2008). Governance and legislation are major drivers of change, and the vision of this approach has been defined as a transition framework focused on water governance, allowing assessment of the city's watermanagement transition to more sustainable states. However, the approach does not include biodiversity targets.

The blue-green city approach (in which "blue" and "green" have evolved in parallel) integrates blue and green urban infrastructure for multiple benefits, including some biodiversity targets (e.g., Lundy and Wade 2011, Rozos et al. 2013, Lawson et al. 2014, Fenner 2017). Unlike the water-sensitive city, however, this approach does not explicitly address the governance or socioeconomic dimensions of urban water management, although some cultural ecosystem services are included (e.g., for public amenity or tourism). The main focus is rainwater retention, infiltration, or climate regulation in urban green spaces (De Vleeschauwer et al. 2014) using urban RWM measures such as swales, ponds, green roofs, or green facades (Oberndorfer et al. 2007, Ahiablame et al. 2012, Voskamp and Van de Ven 2015). Although the contributions of urban water infrastructure to biodiversity and species conservation objectives are recognized in

${ }^{1}$ Department of Ecology, Technische Universität Berlin, ${ }^{2}$ Integrative Research Institute THESys Transformation of Human-Environment-Systems, Humboldt-Universität zu Berlin 
Fig. 1. The transition framework of the water-sensitive city represents a typology of different states of urban water management and describes six distinct but cumulative stages toward the water-sensitive city's vision. Stages I and III-VII are adapted from Brown et al. (2008). In contrast to Brown et al. (2008), stage II centers on urban waterways as transport corridors, whereas blue-way city (V) refers to the rediscovery of urban water bodies in planning and urban design and for environmental protection efforts. The water-sensitive city can be combined with the currently used concept of the blue-green city (VIII), which focuses on the integration of blue and green infrastructure, and can be amplified to the biodiversity-friendly and water-sensitive city (IX) to integrate biodiversity targets in the design of water infrastructure.

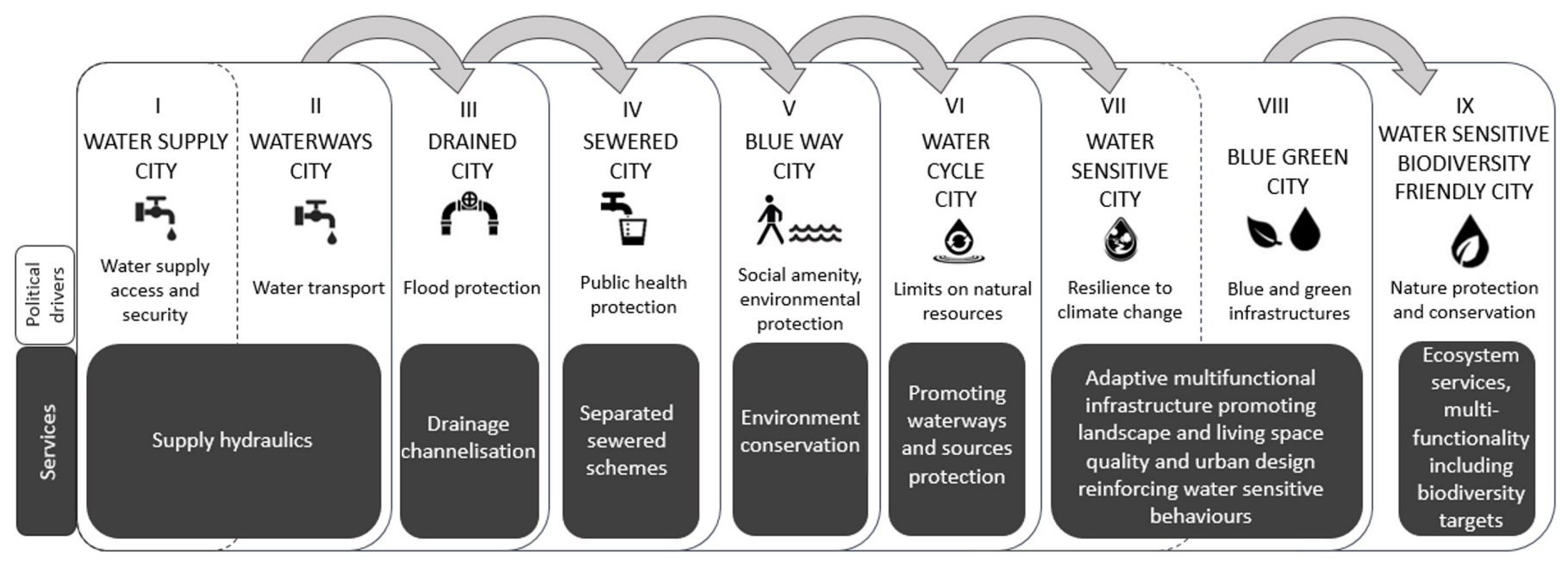

Increasing multifunctionality

these approaches, deeper insights into habitat provision are still lacking (Lundy and Wade 2011, Williams et al. 2014), particularly with regard to quantifying their benefits to biodiversity (Fenner 2017).

In response, here, we extend the current concepts of the "biodiversity-friendly" and water-sensitive city (Fig. 1, stage IX) by integrating biodiversity targets and habitat provision ("habitat services"; Kumar 2010), specifically addressing governance and socioeconomic aspects lacking in the blue-green city approach. This use of ecological design principles is a key strategy for the reconceptualization of water infrastructure (i.e., reducing engineered structural components, development of adaptive impermanent design, incorporating and biomimicking nature's approaches, and enhancing habitat diversity; see Apul 2010). We focus on RWM measures, which are nature-based, cost-effective solutions that simultaneously provide environmental, social, and economic benefits and help build resilience in urban areas (European Commission 2016), specifically measures that are directly related to urban biodiversity such as swales, ponds, rain gardens, green roofs, green walls, and permeable pavements. Here, we use the term RWM measures rather than stormwater management measures to include all types of run-off waters independent of the intensity of the rainfall event, and to avoid confusion between similar terms such as sustainable urban drainage systems, water-sensitive urban designs, and low-impact development because they have different scopes and contexts.

The potential of urban green spaces for biodiversity conservation and restoration has been considered mainly for medium- to largescale green spaces such as urban parks and forests, brownfields, and gardens (e.g., Goddard et al. 2010, Kowarik 2011). Although the roles of scale, connectedness, and heterogeneity of these green spaces have been reviewed and linked to conservation management (Aronson et al. 2017, Lepczyk et al. 2017), the habitat services of small-scale artificial ecological systems such as green roofs and walls, which are designed as technical urban infrastructures, have not been addressed (Garrard et al. 2018). Therefore, our aims are: (1) to review habitat services of urban RWM measures (i.e., swales, ponds, rain gardens, green roofs, green walls, permeable pavement) to identify biodiversity effects of urban RWM measures and knowledge gaps, (2) to illustrate management approaches that enhance the biodiversity friendliness of sustainable urban water management, and (3) based on strategic implementation of RWM measures, to discuss steps to be taken toward achieving a biodiversity-friendly and water-sensitive city.

\section{METHODS}

We conducted a qualitative review of all scientific articles written in English on urban RWM measures indexed in Web of Science following PRISMA guidelines (Shamseer et al. 2015), using keywords covering habitat services and RWM measures (Appendix 1). The advanced keyword search (last updated March 2018) in Web of Science resulted in 830 references related to urban RWM measures in the topic or title fields, of which more than one-half (453) were published after 2011. Filtering the results to exclude papers focused on technical aspects not relevant to our study resulted in 300 articles from "ecology" and "biodiversity conservation". We then screened the titles and abstracts of the remaining articles, eliminating those not related to our topic. In case of doubt, we retained the article. Subsequently, we eliminated 
articles lacking access to the full-text version and sent requests for the most relevant ones. Finally, we performed a full-text review of the remaining articles. The whole process was conducted independently by two reviewers, who then jointly reported a synthesis (Table 1).

Only 140 papers were found that directly addressed habitat services or biodiversity of urban RWM measures. We further included scholarly books and other grey literature found through cross-references, and we considered studies on other urban green elements (e.g., parks, gardens) that indicated habitat services or biodiversity effects of analogous elements in streetscapes. In addition, we summarized management approaches to foster biodiversity (Table 1).

\section{RESULTS}

We synthesized the results from the review of current knowledge on habitat services provided by RWM measures, including drivers and pressures to enhance biodiversity (Table 1). Although research on ponds and green roofs has produced a body of literature (respectively $51 \%$ and $33 \%$ of the fully screened publications on RWM measures), there is a global and consistent lack of studies on other urban RWM measures with regard to habitat services (Table 1, Appendix 1).

\section{Greening city walls and roofs}

The potential of green roofs and walls, also called green facades or living roofs or walls, which are a result of ornamental and horticultural practice, has been described frequently (for reviews, see Francis and Lorimer 2011; for roofs: Oberndorfer et al. 2007, Madre et al. 2014, Thuring and Grant 2016, Van Mechelen et al. 2015a, Blank et al. 2017; for walls: Francis 2011). Analyses of the potential for building attached vegetation and some related ecosystem services (e.g., cooling effects) for several cities revealed that whereas at least one-third of roofs and wall surfaces can be enveloped by greening, depending on building structure and statics (Köhler 2006, Francis and Lorimer 2011, Bates et al. 2013, Nagase and Nomura 2014, Ansel et al. 2016), the architecture of many buildings might not allow the establishment of roof gardens.

Green roofs provide harsh habitats for species (i.e., dryland and ruderal plant species; Dunnett et al. 2008, MacIvor et al. 2011, Lundholm et al. 2014, Brown and Lundholm 2015, Catalano et al. 2016), which cope with pronounced temperature extremes, low water retention, and low nutrient availability (Francis and Lorimer 2011, Francis and Chadwick 2013, Thuring and Grant 2016, Catalano et al. 2016). As with other RWM measures, there are conflicting goals for seed mixtures, e.g., the rapidly filling vegetation canopy required by engineering conflicts with the preference for nondominant species to enhance species diversity (Lundholm et al. 2014). In addition to a limited number of plant species being sown or planted by standardized installation, there is turnover in the species composition over years (Köhler 2006, Köhler and Poll 2010, Catalano et al. 2016). However, green roofs also can be colonized by native species (Madre et al. 2014, Yalcinalp et al. 2017). Compared to dispersal-limited species, anemochorous or zoochorous species are more likely to colonize such roofs or walls spontaneously (Dunnett et al. 2008; Francis 2011). Roofs and, to a lesser extent, walls also provide habitats for arthropod communities (Blank et al. 2017) such as spiders
(Köhler and Schmidt 1997, Brenneisen 2006, MacIvor and Ksiazek 2015, Braaker et al. 2017), collembolans (Schrader and Böning 2006, Davies et al. 2008, Schindler et al. 2011, MacIvor and Lundholm 2011, Rumble and Gange 2013, MacIvor and Ksiazek 2015), insects such as bees, carabids, weevils, cicadas, aphids, ants, moths, butterflies, flesh flies, bottle flies, and grasshoppers (Tonietto et al. 2011, Ksiazek et al. 2012, Madre et al. 2013, Braaker et al. 2014, 2017, Williams et al. 2014, MacIvor and Ksiazek 2015), bats (Pearce and Walters 2012), and birds (Baumann 2006, Brenneisen 2006, Fernandez-Canero and Gonzales-Redondo 2010, Lundholm et al. 2010, Francis 2011, Chiquet et al. 2013, Williams et al. 2014, Thuring and Grant 2016). However, although the implementation of green roofs is frequently mentioned in city biodiversity strategies (e.g., City of Sydney 2012, Ajuntament de Barcelona 2013, Senatsverwaltung für Stadtentwicklung und Umwelt 2014), their conservation value for rare species is as yet poorly documented (Williams et al. 2014).

There are a few studies of green walls, focusing mainly on technical aspects of these vertical greening systems. Although such measures often use a few ornamental species (e.g., Vitis, Hedera, Parthenocissus, Clematis, Wisteria), unvegetated walls can be colonized spontaneously by ruderal species (Francis 2011) and, because they are representative of surrounding species composition, can act as "ecosystem indicators" (Jim and Chen 2010). The walls offer three different habitat types: the top, middle, and bottom of a facade or wall (Francis and Chadwick 2013). In dense cities, due to reduced animal frequentation and potentially low winds, wall colonization is limited (Qiu et al. 2016).

\section{Keeping water in the city through ponds, swales, rain gardens, or permeable paving}

Ponds provide complex aquatic habitats and host a wide range of species, including amphibians (Holzer 2014, O'Brien 2015, Holtmann et al. 2017), fish, waterbirds, macroinvertebrates such as molluscs and insects (Chester and Robson 2013, Hassall and Anderson 2015, Hill et al. 2017, Thornhill et al. 2017), and zooplankton such as cladocerans and rotifers (Mimouni et al. 2015). Aquatic and semi-aquatic habitat structures of urban ponds are largely lost, fragmented, and isolated by urban hydrology (Briers 2014), and also are endangered by multiple pollution risks (Hassall and Anderson 2015). Because temporary ponds are particularly vulnerable to soil drainage and pollution, they are especially threatened compared to other small water bodies (Nicolet et al. 2004). Although the species richness of aquatic fauna is negatively affected by increasing urbanization (Hamer and McDonnell 2008), depending on the design and the urban environment, stormwater ponds contain similar levels of biodiversity and macroinvertebrate community structure compared to natural wetlands (Vermonden et al. 2009, Hassall and Anderson 2015, but see Noble and Hassall 2015), and urban ponds provide habitats for aquatic or semi-aquatic species (Oertli et al. 2002, Vermonden et al. 2009, Hill et al. 2017) and species with an aquatic life-cycle phase (Thornhill 2012). Simultaneously, ponds constitute favorable environments for the development of invasive species (Shochat et al. 2010, Hill et al. 2017), but such undesired aquatic invasions, which occur especially in nutrientrich waterbodies with high vegetation cover, can be mitigated through proper management (Bryant and Papas 2007, Vermonden et al. 2009, Hamer and Parris 2011). 
Table 1. Synthesis of habitat services provided by different rainwater management (RWM) measures; drivers (D) and pressures (P) of biodiversity impacts; and options for the planning, design, and management of RWM measures. Numbers in parentheses corresponded to literature references provided in Appendix 2.

\begin{tabular}{|c|c|c|c|}
\hline RWM measure & Habitat services & Drivers and pressures of biodiversity impacts & Options for planning, design, and management \\
\hline Green roofs (GR) & $\begin{array}{l}\text { Can host various native and non- } \\
\text { native plant species }(4,8,20,24, \\
45,104,114,116,93-95,147, \\
156,158,161) \text {; species are mostly } \\
\text { generalist and cosmopolitan, } \\
\text { associated with dry, exposed, } \\
\text { disturbance-prone habitats (143); } \\
\text { colonizing species are mostly }\end{array}$ & $\begin{array}{l}\text { Local scale: } \\
\text { - D/P: Local settings (e.g., shading, exposure) determine } \\
\text { GR vegetation and resilience; species composition } \\
\text { depends on GR age, size, height, design, and local } \\
\text { climate }(2,15-17,24,45,47,49,93,100,101,124,131 \text {, } \\
\text { 132, } 143,149,155,156,158,160) \text {; plant species function } \\
\text { differently whether in monoculture or mixture }(33,115) ; \\
\text { occurrence of fauna and flora species can depend on }\end{array}$ & $\begin{array}{l}\text { Planning: } \\
\text { Enhance context sensitivity by consideration of local } \\
\text { setting }(2,101) \text {; GR planning at landscape scale for } \\
\text { optimized horizontal and vertical connectivity within } \\
\text { the urban network via stepping-stone effects }(2,14 \text {, } \\
\text { 15, } 42,101-103,131,158) \text {; careful evaluation of the } \\
\text { ecology of wanted (e.g., endangered) species prior to } \\
\text { ex-situ implementation of GR }(149,158)\end{array}$ \\
\hline
\end{tabular}
ruderal and wind dispersed $(24$ 149); high species turnover (24, 45, 93, 149); GRs host birds, reptiles, mammals (such as bats) arthropods such as insects (e.g., bees, butterflies, moths, beetles, grasshopers, flies, mites, collembolans), and spiders ( 5,6 , $11,14,15,17,21,37,42,46,47$. $49,59,65,83,87,95,102,105$, $113,117,122,126,131,133,135$, $146,147,155,156,158,160)$ - Conservation value: GRs host few endangered species; the potential of GRs for ex-situ conservation of species remains unexplored $(5,6,17,20,59,87$, 93, 101, 104, 105, 126, 146, 147, $155,158)$; GRs act as urban "stepping stones" and as ecological corridors for a wide range of animal species $(2,8,14$, $42,117,147,156,158$ )

presence of other key species (110); GRs can act as a source or a trap for endangered species, depending on their mobility and ability to survive the harsh climates of roofs $(5,101,158)$ heterogeneous vegetation structure $(4,17,33,42,47$ Pocially for low-mobility species $(2,15,65, \quad 54,59,63,83,94,101,104,106,143-145,149,153$, 101-103, 146); uniform designs lead to the dominance of 155,160 ); create refuges with sandy, stony, and rocky few plant and animal species $(4,15,83,87,104,131$, 158); high-intensity management does not allow spontaneous vegetation $(15,45,143)$

-D: Substrate and plant species heterogeneity enhance biodiversity $(4,15,47,101,104,106,131,143,149$, 158); shallow substrate and open space allow spontaneous vegetation $(15,102)$; mycorrhizal fungi could enhance soil productivity and plant growth (109, 143) and could promote the establishment of invertebrates that support decomposition and nutrient cycling (101); invertebrates help pest control (101); biomass accumulation promotes biodiversity resilience $(71,101,149)$

\section{Landscape scale:}

- D/P: Regional factors determine vegetation structures and their resilience $(2,15,24,45,47,100,101,155$,

$161)$; surrounding land uses affect biodiversity, especially of invertebrate and bird communities $(2,15,17,32,49$, $65,93,101,124,131,146,156,158,160)$

- D: GRs enhance habitat connectivity during breeding periods (47)

Green facades (GF) Can host few native and nonor living walls areas, and deadwood $(17,49,83,104,108,131,143$, 149); enhance water retention by avoiding sloped roof and using alternative substrates (e.g., biochar; 23, $131,153)$; provide shade with existing building structures or photovoltaic panels to enhance biodiversity $(134,149)$; enhance food source provision for animals (e.g., by using green waste substrates; 4 , $14,23,111,131$ ); constructed wetlands on GRs provide thermal benefits, low irrigation needs, flood tolerance, carbon sink potential, resources for birds, and easy management $(47,140,143)$; use biodiverse and regional seed mixtures adapted to GR climates and that interact positively with other species in the mixture $(8,14,15,20,24,33,70-72,95,99,103$, 113-115, 131, 156, 143, 148, 149); enhance pollinator-friendliness with flowering plants (101); allow spontaneous vegetation areas $(15,42,117,143$, 156)

\section{Management:}

Species management plan to reduce undesirable species $(37,110)$; differentiated management and leaving some biomass on site are recommended ( 71 , 149) native plant species; host mostly herbaceous plants, lichens, mosses, and algae because of the harsh conditions; can host some trees but at low frequency and with low abundance $(52,53,85$, 86); can be colonized by anemochorous and zoochorous species (52), with small and dormant seeds (9), and by ruderal species $(52,53,129)$; provide nesting locations, refuges, and food for invertebrates and birds $(30,44,52,92)$

- Conservation value: needs further research $(9,30,55,52)$
Local scale:

- D/P: local settings (e.g., wall age, substrate types and depth) and building characteristics (e.g., wall material) influence the biota such that older and brick walls harbor more species than younger and concrete walls $(52,36)$

- D: interstices (e.g., cracks, fissures, cavities) attract sediments and seeds and allow species to develop (36, $52,53)$; sediments and humus accumulation help host more species (52); surface moisture is a key element to allow species growth $(52)$

- P: only a few climbing species are adapted to local climate for GFs (52); invasive species can occur occasionally (52); regular cleaning and maintenance of walls disable long-term species establishment (52); climbing species can damage wall structure $(52,96)$; anthropogenic activities would affect avian communities more than environmental conditions of walls (30)

Landscape scale

- D/P: surrounding land uses determine biodiversity (36, refuge during winter (30); favoring support structures $52)$; easy accessibility to GFs by flora and fauna species for climbing plant species (82)

favor their dispersal

Planning:

Planning of GFs at landscape scale is crucial to allow optimal connectivity within the urban matrix (both horizontal and vertical) and enhance the stepping-stone effect $(52,92)$; GFs can be coupled with GRs to maximize connectivity and biodiversity $(52,92)$

Design:

Designing wall surfaces with complex 3-D shape improves habitat diversity (52); designing walls surfaces with cracks and fractures allows sediment and humus deposit and plant development $(52,53)$; different wall materials and substrates enhance habitat diversity (52); some plant species (e.g., Hedera helix) can benefit other species' establishment by mitigating microclimates (52); installing layered systems on wall surface prevents root-related damage (52); designing GF with evergreen species can be beneficial for bird species by providing food and

for climbing

GF are recommended over living walls because they require less maintenance and have lower costs (125); maintaining sufficient irrigation allows consistent evapotranspiration and faster growth for a proper cooling effect (22) 
Ponds (PO)

Swales and rain gardens (SW)
Act as stepping stones for species Local scale: dispersal and genetic exchange $(18,26,61,68,69,121,142)$; hos various water-dependent species such as macrophytes, amphibians, fish, waterbirds, insects (e.g., Hemiptera, Odonata, Coleoptera), molluscs, cladocerans, amoebae, rotifers ( 3 , $18,19,26,31,34,48,50,51,62$, $64,68,69,73,76,77,78,80,81$, $112,119,121,123,127,132$, $141,142,151,152,154)$; species composition of artificial POs does not differ from that of natural POs $(13,16,18,26,40,68,69$, $76,77)$; associated species serve as food sources for terrestrial species $(7,26,142)$; provide refuges for endangered species ( 1 , $3,18,26,141,68,69,75,77) ; \mathrm{PO}$ creation helps to restore fragmented wetlands $(26,35,77$, 138); POs at greater spatial scale in cities have increasingly dissimilar communities of macroinvertebrates because of high variability in historical and environmental factors (76)
SW host a limited number of plant species, often neophytes; can host amphibians (64); can host invertebrate species that are not found in garden-bed type greenspaces (89-91); can act as ecological corridors (89-91) - Conservation value: unknown
- D/P: species composition and abundance depend on

PO characteristics (e.g., size, shade, water depth, habitat diversity, historical factors) and species dispersal patterns $(3,12,13,18,25,26,38,39,57,64,68,69$, 150 ); high dispersal ability of semi-aquatic species improves PO resilience $(62,76)$; species composition is related to PO design and location rather than function $(27,69,74,97,112)$; presence of certain organisms such as fish or introduced species can negatively or positively affect PO species communities and habitats $(18,26,58$, $68,69,76,107,130,136,137,151)$; local environment affects food network and biodiversity of small compared to larger POs $(26,43)$; communities develop within $2-3$ yr and vary greatly in time $(68,69,18,158)$ - P: urban context and insufficient light exposure foster proliferation of invasive species and decrease biodiversity $(66,76,142,151)$; PO shade and size affect frogs (154); water containing periods of stormwater retention POs can be too short to enable species establishment $(16,29)$; certain management practices and anthropogenic disturbances such as sediment removal negatively affect biodiversity $(18,26,29,66-$ 76,120 ); pollutant desposition and eutrophication reduce biodiversity $(18,26,29,68,69,76,84,88,97)$ - D: vegetation, sufficient hydroperiod, variable water depth, few impervious surfaces, and site age favor insect and amphibian presence $(64,73,81)$; good sediment and water quality (e.g., low conductivity, stable oxygen, high $\mathrm{pH}$, and low nutrient loads) along with sufficient hydroperiod foster biodiversity $(18,26,66,68,69,142)$

Landscape scale:

- D: high PO density and connectivity enable species dispersal $(18,26,64,68,69,73,77,107)$

- D/P: neighboring land uses affect POs (60); proximity of POs to continuous forest fosters amphibian conservation in urban areas $(56,64,84)$; aquatic insect richness depends on the density of POs (and water depth) and proportion of surrounding buildings (73); disturbance in one PO might not affect other nearby POs in small catchment areas (76)

- P: barriers within the urban network reduce mobility of aquatic fauna $(10,69,78,157)$

\section{Local scale:}

- D: structural diversity enhances habitat diversity (91); using flowering species and various plant life forms significantly enhances invertebrate diversity $(89,91)$; native plant species favor amphibians (64)

- D/P: SW shape influences biodiversity potential (90); lateral slope affects biodiversity, with steeper slopes associated with higher biodiversity (89); lower pH observed in SWs increases invertebrate activity aboveground (89); leaf litter depth significantly affects invertebrate richness, abundance, and diversity, offering nutritional and growth substrate and refuges $(90,91)$ - P: human activities can affect SW diversity (91)

Landscape scale:

- D/P: location and connectivity within the urban network are important for SW biodiversity $(90,91)$

\section{Planning:}

Integrate POs into nature conservation legislation

and promote PO implementation $(68,69,73,80,81$,

$139,142,154)$; implement POs to optimize density and connectivity at local and regional scales, considering surrounding land uses $(18,26,29,41,57$, $67-69,73,78,123,142$ )

Design:

Diverse POs with complex morphology provide diverse habitats (e.g., type of species, water chemistry; 13, 18, 26, 48, 62, 67-69, 81); avoid steep slopes to allow amphibians to move out of POs (68, 123); maintain light availability $(51,68,80,142)$; implement diverse terrestrial and aquatic plant species to support submerged and emergent vegetation $(13,62,68,80,142)$; include sequential water treatment to enhance water quality $(18,62$, $141)$; create interconnections of temporary and permanent POs $(67,119,141)$; focus on requirements of target species (62)

\section{Management:}

Better management can significantly improve biodiversity $(76,142)$; PO management without considering biodiversity occurs mostly due to lack of knowledge of PO ecology $(76,120)$; guidelines needed for biodiversity-friendly management plans (e.g., reducing shading and nutrient inputs, maintaining vegetation within $100 \mathrm{~m}$ of PO; 68,69 , $77,120,142)$; physical and social surroundings must be considered for PO management; POs should be implemented where surrounded by sufficient green spaces (60); aesthetic and attractiveness purposes of urban POs require intensive management that promotes biodiversity (76); controling human access to POs prevents unwanted species introduction (26, 68); POs are absent in nature conservation legislation; most POs are garden POs, poorly known and hardly accessible $(57,68,69)$; temporary POs should be converted to permanent POs (80); citizen science can be used to collect data for better management and to increase awareness among citizens (108)

\section{Planning:}

Plan SWs at a wide scale to consider surrounding land uses and connect SWs with the urban green network $(89,91)$

Design:

Favor larger and more rounded over narrow linear SWs (89); design SWs with flowering species and different life forms to offer various strata (89); use gravels or stones to offer refuges, and design steep slopes to enhance habitat diversity (89); surround SWs with hedges to reduce anthropogenic activities within SWs (89); substrates and plant species influence soil stability (128); steeper slopes and midstratum vegetation foster biodiversity (89); using compost in the substrates could be beneficial for plant growth and pollutant removal (28)

\section{Management:}

Maintain consequent leaf litter depth to offer habitat possibilities for soil invertebrates $(90,91)$; late mowing (e.g., late autumn) is more beneficial than in late summer for plant development (79)
The few existing studies provide evidence of the potential of swales and rain gardens for biodiversity conservation by offering habitats for flora and fauna (Kazemi et al. 2009a,b, 2011). However, because swales are civil engineering structures that must properly infiltrate set amounts of water, their highly regulated design and maintenance standards inhibit the establishment of spontaneous species. 
Although there are few studies of the biodiversity effects of permeable pavements, such RWM measures can support the dispersal of small wildlife and seeds by connecting biodiversityharboring patches (Säumel et al. 2016).

\section{DISCUSSION}

To our knowledge, this is the first study to focus explicitly on biodiversity effects of the wide set of existing RWM measures and to identify approaches to strengthen biodiversity. We found that, because engineers tend to analyze the functioning of such measures, studies are dominated by parameters such as water filtration efficiency, cooling effects, and pollutant removal. In contrast, studies focusing on biodiversity effects are scarce, except for ponds, wetlands, rivers (e.g., Céréghino et al. 2014), and green roofs (e.g., Oberndorfer et al. 2007, Thuring and Grant 2016). RWM measures provide a wide range of wildlife habitats (Oberndorfer et al. 2007, Francis and Lorimer 2011, Lundy and Wade 2011, van Leeuwen et al. 2012, Williams et al. 2014, Thuring and Grant 2016, Hill et al. 2017; Table 1), and RWM measures that follow ecological design principles reduce impacts on biodiversity and support local wildlife communities (Ignatieva and Ahrné 2013, Ruddick, 2016). In contrast to traditional civil engineering structures, ecologically designed RWM measures represent novel ecosystems (Hobbs et al. 2006) that are relevant for species conservation, helping species to adapt to severe habitat transformation resulting from high-density urbanization (Kowarik 2011, Chester and Robson 2013, Williams et al. 2014, Ikin et al. 2015, Van Mechelen et al. 2015a, Lepczyk et al. 2017). Our review provides evidence that besides the quantity of urban green spaces, the multifunctionality of urban landscapes is enhanced by habitat quality and the biodiversity-friendly design of green and blue infrastructure, including urban RWM measures. Biodiversity is thus a crucial indicator of the sustainability of urban water management (van Leeuwen et al. 2012) and should be included in monitoring programs.

The categorization of RWM measures as civil engineering structures, and the resulting related rules, limit efforts to optimize the biodiversity friendliness of their design and management. By developing regulations based on knowledge exchanges between experts of different sectors, biodiversity-friendly interventions can increase the multifunctionality of urban RWM measures. Such measures need to be considered as an integral part of the urban infrastructure, not just as a technical means for managing stormwater.

\section{Shaping biodiversity by planning and design}

Urban water bodies are often channeled and are far removed from natural riparian dynamics. Because small-scale interventions are currently being reshaped and renaturalized, following the European Water Framework, they have the potential to provide habitat for species. In addition to the rehabilitation of highly modified urban water bodies, optimization of RWM measures design is a crucial tool for promoting biodiversity through the creation of habitats for targeted species (Savard et al. 2000, Palmer et al. 2004, Kazemi et al. 2009a,b) and for improving the overall provision of ecosystem services (Ahiablame et al. 2012, Ikin et al. 2015, Lundholm and Williams 2015). Although urban pilot projects consider RWM measures, the importance of such measures continues to be underestimated and their upscaling and mainstreaming is slow and limited.
Our review found that ponds can affect larger scales and can allow habitat for a wide range of species (Nicolet et al. 2004, Hamer and McDonnell 2008, Vermonden et al. 2009, Thornhill 2012, Apinda Legnouo et al. 2014, Chester and Robson 2013, Briers 2014, Jeanmougin et al. 2014, Hassall and Anderson 2015, Hill et al. 2017), whereas effects of garden ponds, rain gardens, and green walls remain at the garden plot level (Kazemi et al. 2009b, Francis 2011, Chester and Robson 2013, Hill and Wood 2014). Because patch size, habitat quality, and frequent implementation of green walls and roofs are key factors in reducing isolation effects (Mayrand and Clergeau 2018), the contribution of RWM measures to the blue-green infrastructure can be optimized within the urban matrix through efficient integration that takes into account the surrounding land-use types and the species composition of neighboring green spaces. Identification of target areas is crucial in the planning of RWM measures, and tools such as the "integral index of connectivity" (Pascual-Hortal and Sauroa 2006) are found to be useful in quantifying the capacity to interact with other green spaces (Fenner 2017). Decentralized systems are strongly related to the landscape context; because RWM measures need to involve a wide range of actors to achieve good integration within the urban landscape, the inclusion of local property owners is critical to their efficient implementation. To optimize overall connectivity within the urban matrix, the mainstreaming and combination of such measure implementations should be planned at the landscape scale. Urban authorities therefore need to identify target areas to implement biodiversity-friendly RWM measures within the bluegreen networks (Figs. 2 and 3).

We found that architectural restrictions and regulations often present obstacles to the design and installation of RWM measures such as green roofs on existing buildings (Mayrand and Clergeau 2018), and RWM measures planning is frequently realized by technical engineers using standard designs and seed mixtures (e.g., swales with a mean of $<10$ species). For example, the Berlin Standard for Swales consists of $>60$ different rules, but only a limited standard for greening (BWB 2012). Design decisions are dominated by the main function of managing rain water, partially in terms of aesthetics, and rarely consider biodiversity targets. RWM measures design needs to be adapted to the life cycle of target species, for example, providing suitable sites for oviposition, sunbathing, or winter grounds (Hauck and Weisser 2015, Hill et al. 2017, Lepczyk et al. 2017). Several studies find that ecosystem services are positively correlated with the functional diversity of a measure (Nelson et al. 2009, Van Mechelen et al. 2015b). In addition, plant community diversity and functional trait composition are important for ecosystem services provision (Lavorel 2013), and functional diversity can be considerably enhanced by optimal design that diversifies species composition, vegetative structures, and substrate types, and integrates other materials such as dead wood or stones (see key practices summarized in Table 1 for each RWM measure). While combinations of different types of measures highly benefit biodiversity, maintaining unified ecological conditions with more complex structures is essential because they enable species dispersal, especially by green roofs and walls that are often linked but offer conditions too disparate to be fully beneficial for urban wildlife (Mayrand and Clergeau 2018). 
Fig. 2. Status quo maps were presented to local stakeholders as a basis for goal prioritization from different perspectives. See details on the methodological approach in Fig. 3. These maps show the sample area of Berlin Schöneberg studied within the KURAS project (Konzepte für Urbane Regenwasserbewirtschaftung und Abwassersysteme, http://www.kuras-projekt.de/). (A) The existing pattern and connectivity of biodiversity-relevant elements of the green infrastructure (e.g., public parks, playgrounds, brownfields, cemeteries) were assessed. The small dark-green arrows indicate the intraconnectivity of these elements within the sample areas, and the large light-green arrows illustrate the interconnectivity between elements of the sample area within the broader urban matrix. (B) Rainwater management measures that were selected and placed within a participatory simulation game (Fig. 3) strongly enhanced connectivity within these elements.

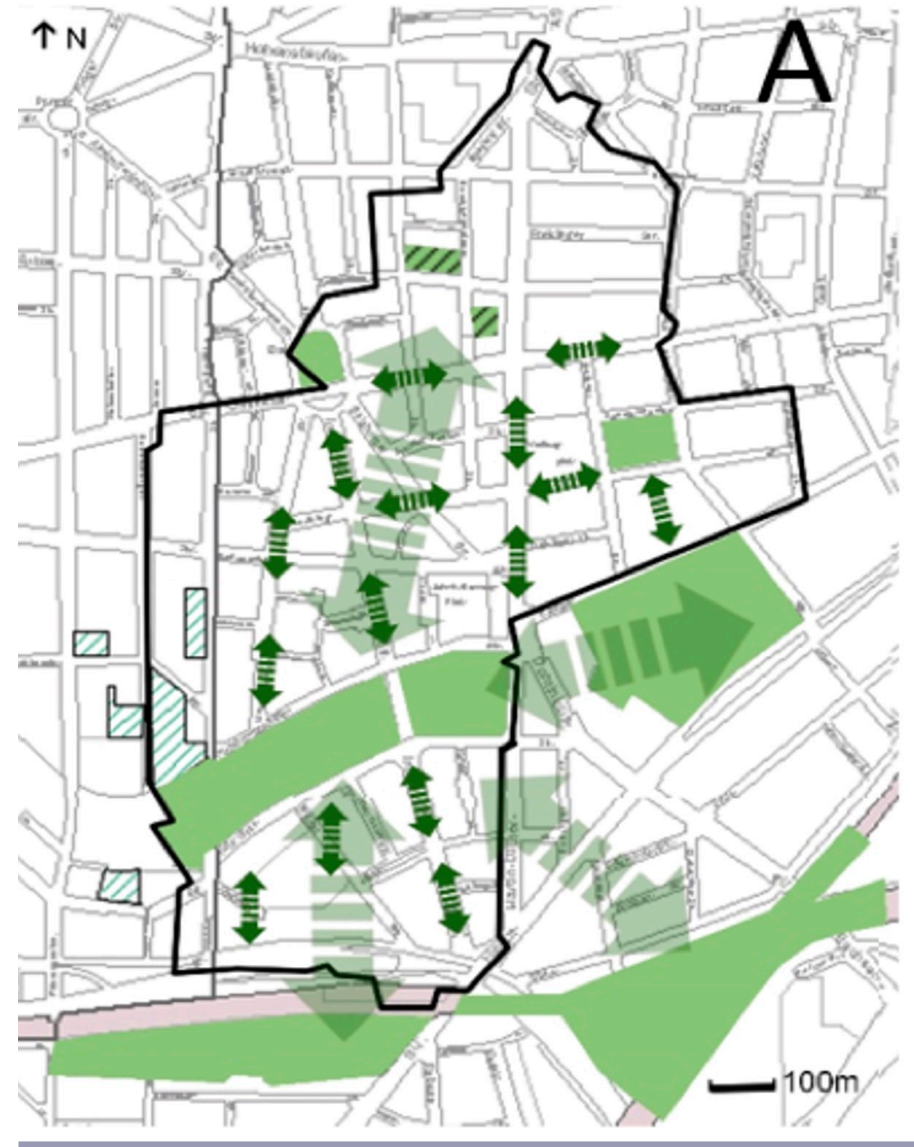

\section{Shaping biodiversity by intervention}

RWM measures are designed to be low maintenance, and specific interventions such as mowing or inserting deadwood or different soil substrates can considerably benefit biodiversity. Because plant communities change over time and can become quite different from the initial plantings, we should also consider longterm effects (e.g., Catalano et al. 2016). Because many flora and fauna species not originally present can establish sustainably over time, consideration of later successional habitats is critical to sustaining the biodiversity-enhancing effects of RWM measures. However, to ensure the functionality of RWM measures, some trajectories such as the incorporation of woody species could be limited; for example, intervention to maintain favorable conditions on newly built green roofs during stressful periods in the initial years can enhance perennial recruitment, benefiting long-term coverage (Walker and Lundholm 2018).

Applying disturbances to an ecosystem (e.g., controling the hydroperiod of a waterbody, mowing the vegetation) can affect

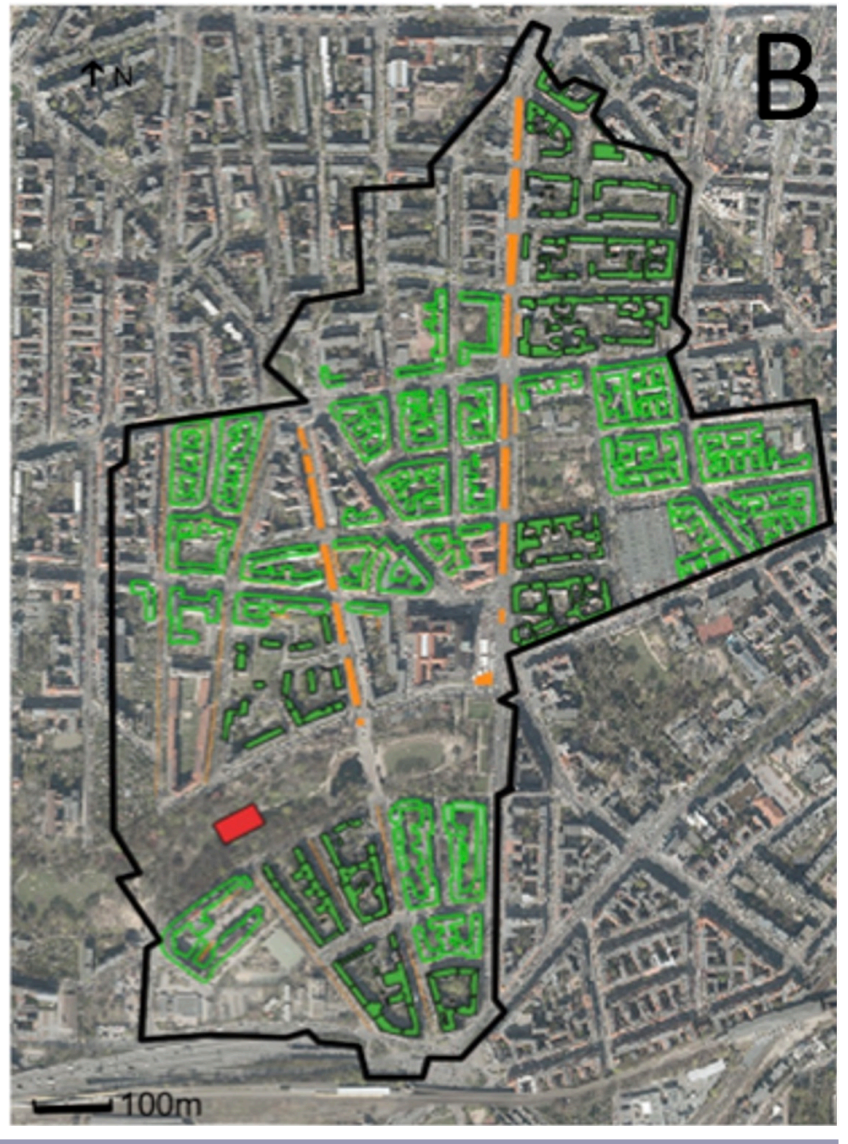

its structure and function (Hobbs and Huenneke 1992), so episodic intervention such as restoration, or regular intervention such as mowing, can be used to enhance the ecosystem potential by reducing unwanted species (e.g., woody species on green roofs, fish or invasive species in waterbodies) and by increasing the number and variety of target species (Hamer and McDonnell 2008, Vermonden et al. 2009, Chester and Robson 2013, Roy et al. 2014, Hill et al. 2017, Miller et al. 2017). In some cases, interventions can help to prevent wetlands and ponds from functioning as ecological traps for certain species (Sievers et al. 2018), so long-term monitoring of biodiversity impacts for all interventions (Table 1) is recommended.

Interventions can also lead to unwanted effects for biodiversity or the perception of RWM measures. For example, Jurczak et al. (2018) showed that the restoration of shady urban ponds created a sunbleak (Leucaspius delineatus) migration and led to the loss of daphnid species. The reduction of mowing regimes also often makes the vegetation appear unkempt, which citizens may 
Fig. 3. General planning steps for rainwater management (RWM) measures. Adapted from the strategic implementation of urban green infrastructure steps developed by Norton et al. (2015). (A) Step I consists of identifying the weakest areas of a city where RWM measures are most needed, and step II consists of characterizing these areas depending on the target purpose (i.e., identifying quantity and quality of existing structures, considering interrelations to adjacent areas). Step III consists of optimizing the quality of RWM measures before building new measures. Step IV focuses on the weakest areas of the targeted neighborhoods to define the best combination of RWM to implement (step V). (B) The KURAS (Konzepte für Urbane Regenwasserbewirtschaftung und Abwassersysteme, http://www.kuras-projekt.de/) approach for participatory planning of RWM measures given for a sample area in Berlin. RWM measures were selected and placed across a neighborhood within a participatory simulation game. For details, see Matzinger et al. (2017).

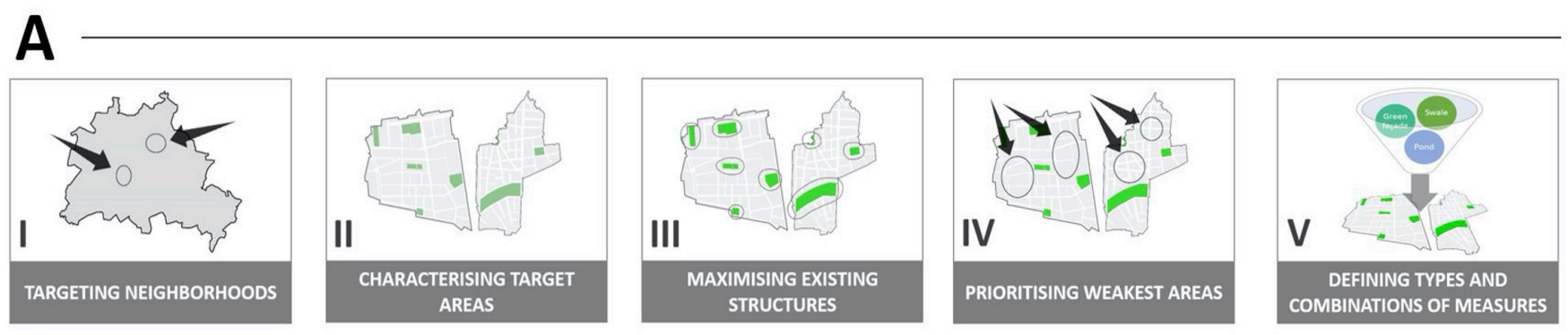

B
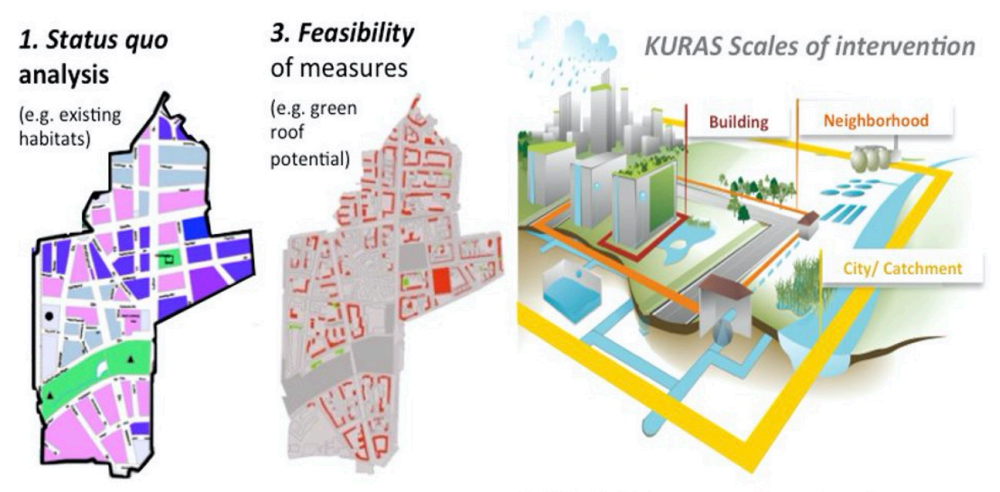

4. KURAS Measure-Effect Matrix:

2. Priorization of effects to be achieved by stakeholders
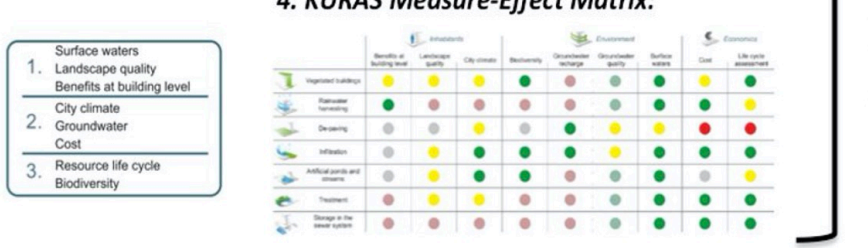

Participatiory planning:
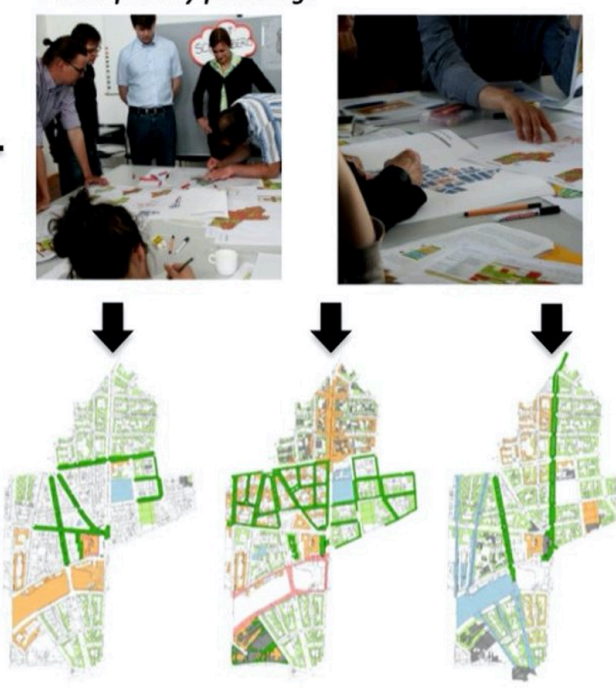

Set of Suitable combinations of measures and assessment of achieved effects perceive negatively (Mathey et al. 2015), and is a barrier for public acceptance. Including local residents in maintenance and interventions can help promote acceptance of such green spaces.

\section{Combining human activity and biodiversity friendliness}

RWM measures planning and implementation need to consider social-ecological perspectives. Combining human activity and biodiversity friendliness enables reconfiguration of urbanized landscapes to leave more room for biodiversity conservation without restricting anthropogenic use of those spaces (Francis and Chadwick 2013). Urban green spaces already support biodiversity-friendly human activities, and RWM measures represent a realistic option for ensuring ecosystem services and nature protection without compromising societal use. Applying these objectives to RWM measures is a key management tool for addressing the massive scale of habitat loss from anthropogenic activities, especially in cities, where restoration and preservation solutions are hard, if not impossible, to implement (Francis and Chadwick 2013).

Unlike restoration or preservation actions, the combination of human activity and biodiversity friendliness can be retrofitted to existing built-up areas at broader scales and does not need a previous state or an unimpacted biodiversity template for objective definition and evaluation. However, such interventions often deliver limited results compared to what can be achieved through traditional preservation or restoration actions. Although RWM measures are most likely to enhance "ordinary" biodiversity that can be experienced by people every day in the urban outdoors, restoration actions can be achieved through 
measures such as ponds and offer better results in terms of biodiversity conservation of more threatened species (Hassal and Anderson 2015). RWM measures provide multiple habitat types and extend the blue and green networks in urban environments (Francis and Lorimer 2011, Ignatieva et al. 2011, Francis and Chadwick 2013, Kim et al. 2017). Our review finds that local-scale action has an effect on metapopulations at wider scales (Francis and Chadwick 2013). Because of their capacity, for example, to provide habitats or food for a wide range of species, some keystone species exert a strong influence on the respective ecosystem independent of abundance or size (Mills et al. 1993). These species should be considered when building RWM measures and other blue-green infrastructure (Francis and Chadwick 2013).

Our review found that implementation of RWM measures in densely built areas need to address some issues such as not damaging buildings (e.g., climbing species on green walls). However, the greatest challenge is acceptance by citizens because RWM measures can also result in nuisances (Hoang and Fenner 2016), including insects such as mosquitoes, which are undesirable in an urban environment (Francis 2011, Mackintosh and Davis 2013). Also, wild vegetation often is perceived negatively compared to aesthetically well-kept vegetation, which is perceived to confer healthy ecosystem services (Dobbie and Green 2013; but see contrasting evidence for spontaneous growth roadside vegetation, Weber et al. 2014). Because public engagement is crucial for urban biodiversity conservation, and communities are more likely to support green interventions if they are aware of the services they provide (Hassal and Anderson 2015), combining human activities with biodiversity friendliness is a key strategy because it promotes positive human-nature interactions. In addition, partnership with local stakeholders has been shown to enhance the economical aspect of decentralized systems, including green approaches, which, compared to centralized systems such as detention tanks, can be cost-competitive (Montalto et al. 2007).

\section{Biodiversity effects of rainwater management measures, barriers, and knowledge gaps}

Despite the growing body of literature, the multifunctionality of RWM measures remains underexploited, with only their primary function of water management taken into consideration, and their additional benefits considered only coincidentally (Fenner 2017). Existing research on other benefits, especially supporting biodiversity, is based on short-term studies. Although the need for long-term experiments to validate and to assess precisely the conservation value of RWM measures is repeatedly stated in literature (e.g., Chester and Robson 2013, Roy et al. 2014, Williams et al. 2014, Thuring and Grant 2016, Blank et al. 2017), little is known about the interactions between different ecosystem services (e.g., water treatment functions, habitat services, cultural services) and the quantification of those services. Although a number of relatively easy-to-measure indicators have already been used to assess the effects of urbanization on biodiversity, such as vegetation cover and proportion of native and exotic species, they are only proxies and are insufficient for measuring biodiversity outcomes (Lenth et al. 2006, Garrard et al. 2018). In addition, little is known about the effectiveness of RWM measures; better quantification will help overcome the lack of confidence among urban developers. The lack of demonstration projects is also reported as a barrier for the mainstreaming of
RWM measures (Kuller et al. 2017). Interestingly, although RWM measures have been implemented in cities for decades, they are still seen as novel solutions (e.g., in the UK, see Fenner 2017). Wider use of RWM measures will require systematic monitoring and evaluation to demonstrate their benefits.

The current lack of monitoring regulation illustrates the global lack of effective legislation and governance for the implementation of RWM measures and, more generally, biodiversity-friendly infrastructures. The complex interconnections of RWM measures as elements of the urban landscape and their multiple functions regarding ecosystem services need to be translated clearly into governance rules and legislation at different levels of authorities (e.g., from local to international agencies; Aronson et al. 2017, Fenner 2017, Kim et al. 2017). Explicit multiscale analysis will reduce the barriers to strategic implementation of multifunctional measures adapted to the local context (e.g., environment, climate, social perception, administration, or resources). Multistakeholder involvement and fluid collaboration between stakeholders is essential for designing, implementing, and maintaining biodiversity-friendly and water-sensitive cities. Differences in knowledge among the stakeholders can be addressed through better sharing of knowledge and the development of a common understanding. Because the perception of such urban ecosystems by citizens is limited (Hassall 2014, McGoff et al. 2013), educational means can help increase awareness of the multiple benefits of RWM measures and promote acceptance (Goddard et al. 2010, Ikin et al. 2015).

The effectiveness of multifunctional and multiscale RWM measures depends on the implementation process, which needs be integrated in the existing landscape and urban planning to adapt the design, combination of measures, and connectivity to a given area. Because not all services can be provided by one measure, the prioritization of desired functions and benefits is necessary. Different steps of a pertinent implementation can be adapted to favor different targets defined by local stakeholders (e.g., enhancement of landscape quality, mitigation of urban heat islands), and improving biodiversity can be considered.

In the KURAS project (Konzepte für Urbane Regenwasserbewirtschaftung und Abwassersysteme, http://www.kuras-projekt. de/), target areas were first identified (Fig. 2) and RWM measures were selected and simulated across the scales of two neighborhoods in Berlin, from building via quarter to catchment level, within a participatory simulation game (Fig. 3). The critical evaluation of status quo, the feasibility of RWM measure implementation, and the simulated impact were assessed, and discussions were held with local stakeholders to achieve informed decision-making. This process enabled coordinated and effective planning of RWM measures from landscape to building scale, as well as effective collaboration and coordination among the different stakeholders involved. In addition, a range of actors (including building and residential greenspace owners) developed a non-standardized design of the decentralized measures, ensuring both variety in types and design of measures, thus amplifying their ecological weight.

\section{CONCLUSIONS}

The biodiversity-friendly and water-sensitive city's vision proposes a decentralized system that has been popular in debates 
on the future-proof city for several decades. However, its efficiency in improving overall urban resilience has yet to be proven in practice. The institutional barriers toward decentralized systems (Brown and Farrelly 2009) and, more specifically, toward ecological design implementation are primarily legislation and the organizational capacity of stakeholders. The lack of studies on the effectiveness of different ecological designs currently limits mainstreaming of existing scientific knowledge for informed decision-making, other than in a few examples of best practices. To overcome these obstacles and facilitate biodiversity-friendly RWM measures, ecological designs need to be integrated in planning at different scales, and robust partnerships among all the actors are necessary. Interdisciplinary collaboration among the multiple stakeholders in the design, implementation, and management of RWM measures, involving public and private partners, also has the potential to increase citizen awareness of sustainable water use in urban areas.

Because of economic and environmental impacts, infrastructure investment and replacement will be a gradual process using hybrid technologies (Sapkota et al. 2016). The first steps toward sustainable urban water management have been undertaken, through water saving and re-use of water, and through implementation of urban RWM measures (e.g., Brown et al. 2006, Dietz 2007, Ahiablame et al. 2012, Conte et al. 2012), mainly in cost-inefficient sectors of water infrastructure, in new buildings or new neighborhoods. To develop tomorrow's sustainable city, implementation of RWM measures in existing neighborhoods through urban restructuring needs to be extended beyond the few existing examples.

In summary, our review has highlighted the need to enhance the habitat quality of single RWM measures at the building level, and the need, on the whole city scale, to integrate such measures into planning of ecological networks in different neighborhoods. Because biodiversity-friendly urban RWM measures have the potential to maximize patch and corridor size, increasing their number and density will improve the habitat quality of the urban green infrastructure. To enhance connectivity at the regional scale, such measures should be implemented preferentially in corridor areas. Integration of such measures will provide many environmental, ecological, socio-cultural, and economic benefits such as aesthetic and recreational value, food provision, microclimate regulation, and energy savings, thus fulfilling the water-sensitive and biodiversity-friendly city's vision, which is based on infrastructure multifunctionality to provide as many ecosystem services as possible.

Responses to this article can be read online at: https://www.ecologyandsociety.org/issues/responses. php/12386

\section{Author Contributions:}

Conceptualization of the study: I.S.; Implementation and adaptation of the study: L.P. and I.S.; Methodology design and validation: L.P. and I.S.; Draft writing: L.P., I.S.; Review and editing: L.P. and I.S.; Visualization: L.P. and I.S.; Supervision, funding acquisition, project administration: I.S.

\section{Acknowledgments:}

We thank the Bundesministerium für Bildung und Forschung (Federal Ministry of Education and Research) for funding (033W013A-P) and the colleagues and stakeholders involved in the KURAS project (https:/lwww.kuras-projekt.de) for fruitful discussions. We thank the anonymous reviewers for helpful comments on earlier versions of the manuscript and Amal Chaterjee for improving our English.

\section{Data Availability:}

All relevant data are available in the appendices.

\section{LITERATURE CITED}

Ahiablame, L. M., B. A. Engel, and I. Chaubey. 2012. Effectiveness of low impact development practices: literature review and suggestions for future research. Water, Air, and Soil Pollution 223:4253-4273. https://doi.org/10.1007/s11270-012-1189-2

Ajuntament de Barcelona. 2013. Barcelona green infrastructure and biodiversity plan 2020. Ajuntament de Barcelona, Barcelona, Spain. [online] URL: https://ajuntament.barcelona.cat/ecologiaurbana/ sites/default/files/

Barcelona $\% 20$ green $\% 20$ infrastructure $\% 20$ and $\% 20$ biodiversity $\%$ 20plan\%202020.pdf

Ansel, W., J. Zeidler, T. Esch, H. Bornholdt, A. Schmid, H. Wahle, B. Reichmann, H. Müller, B. Eisenberg, F. Ludwig, and D. Schönle. 2016. Kommunale gründach-strategien inventarisierung, potentialanalyse, praxisbeispiele. Deutscher dachgärtner verband e. V. -DDV, Nürtingen, Germany.

Apinda Legnouo, E. A., M. J. Samways, and J. P. Simaika. 2014. Value of artificial ponds for aquatic beetle and bug conservation in the Cape Floristic Region biodiversity hotspot. Aquatic Conservation: Marine and Freshwater Ecosystems 24(4):522-535. https://doi.org/10.1002/aqc. 2413

Apul, D. 2010. Ecological design principles and their implications on water infrastructure engineering. Journal of Green Building 5 (3):147-164. https://doi.org/10.3992/jgb.5.3.147

Aronson, M. F. J., C. A. Lepczyk, K. L. Evans, M. A. Goddard, S. B. Lerman, J. S. MacIvor, C. H. Nilon, and T. Vargo. 2017. Biodiversity in the city: key challenges for urban green space management. Frontiers in Ecology and the Environment 15 (4):189-196. https://doi.org/10.1002/fee.1480

Bates, A. J., J. P. Sadler, and R. Mackay. 2013. Vegetation development over four years on two green roofs in the UK. Urban Forestry and Urban Greening 12(1):98-108. https://doi. org/10.1016/j.ufug.2012.12.003

Baumann, N. 2006. Ground-nesting birds on green roofs in Switzerland: preliminary observations. Urban Habitats 4 (1):37-51. [online] URL: http://www.urbanhabitats.org/v04n01/ birds full.html

Berliner Wasserbetriebe (BWB). 2012. Mulden-Rigolen-Systeme: Grundsätze. Regelblatt 600. Berliner Wasserbetriebe, Berlin, Germany. [online] URL: https://www.bwb.de/de/assets/downloads/ rgbl600 11-2012.pdf 
Blank, L., A. Vasl, B. Y. Schindler, G. J. Kadas, and L. Blaustein. 2017. Horizontal and vertical island biogeography of arthropods on green roofs: a review. Urban Ecosystems 20:911-917. https:// doi.org/10.1007/s11252-016-0639-9

Braaker, S., J. Ghazoul, M. K. Obrist, and M. Moretti. 2014. Habitat connectivity shapes urban arthropod communities: the key role of green roofs. Ecology 95(4):1010-1021. https://doi. org/10.1890/13-0705.1

Braaker, S., M. K. Obrist, J. Ghazoul, and M. Moretti. 2017. Habitat connectivity and local conditions shape taxonomic and functional diversity of arthropods on green roofs. Journal of Animal Ecology 86(3):521-531. https://doi.org/10.1111/1365-2656.12648

Brenneisen, S. 2006. Space for urban wildlife: designing green roofs as habitats in Switzerland. Urban Habitats 4(1):27-36. [online] URL: http://www.urbanhabitats.org/v04n01/wildlife full. $\underline{\mathrm{html}}$

Briers, R. A. 2014. Invertebrate communities and environmental conditions in a series of urban drainage ponds in eastern Scotland: implications for biodiversity and conservation value of SUDS. Clean Soil Air Water 42(2):193-200. https://doi.org/10.1002/ clen.201300162

Brown, C., and J. Lundholm. 2015. Microclimate and substrate depth influence green roof plant community dynamics. Landscape and Urban Planning 143:134-142. https://doi.org/10.1016/j. landurbplan.2015.07.009

Brown, R. R., and M. A. Farrelly. 2009. Challenges ahead: social and institutional factors influencing sustainable urban stormwater management in Australia. Water Science and Technology 59(4):653-660. https://doi.org/10.2166/wst.2009.022

Brown, R. R., N. Keath, and T. Wong. 2008. Transitioning to water sensitive cities: historical, current and future transition states. In R. Ashley, editor. Conference proceedings: 11th international conference on urban drainage. IWA Publishing, London, UK.

Brown, R. R., L. Sharp, and R. M. Ashley. 2006. Implementation impediments to institutionalising the practice of sustainable urban water management. Water Science and Technology 54 (6-7):415-422. https://doi.org/10.2166/wst.2006.585

Bryant, D., and P. Papas. 2007. MarronCherax cainii (Austin) in Victoria - a literature review. Arthur Rylah Institute for Environmental Research Technical Report Series 167. Department of Sustainability and Environment, Heidelberg, Australia. [online] URL: https://nla.gov.au/nla.obj-529094233/ view

Catalano, C., C. Marcenò, V. A. Laudicina, and R. Guarino. 2016. Thirty years unmanaged green roofs: ecological research and design implications. Landscape and Urban Planning 149:11-19. https://doi.org/10.1016/j.landurbplan.2016.01.003

Céréghino, R., D. Boix, H.-M. Cauchie, K. Martens, and B. Oertli. 2014. The ecological role of ponds in a changing world. Hydrobiologia 723:1-6. https://doi.org/10.1007/s10750-013-1719$\mathrm{y}$

Chester, E. T., and B. J. Robson. 2013. Anthropogenic refuges for freshwater biodiversity: their ecological characteristics and management. Biological Conservation 166:64-75. https://doi. org/10.1016/j.biocon.2013.06.016

Chiquet, C., J. W. Dover, and P. Mitchell. 2013. Birds and the urban environment: the value of green walls. Urban Ecosystems 16:453-462. https://doi.org/10.1007/s11252-012-0277-9

City of Sydney 2012. Greening Sydney plan. City of Sydney, Sydney, Australia. [online] URL: https://www.cityofsydney.nsw. gov.au/-/media/corporate/files/2020-07-migrated/files g/ greeningsydneyplan.pdf?download=true

Conte, G., A. Bolognesi, C. Bragalli, S. Branchini, A. De Carli, C. Lenzi, F. Masi, A. Massarutto, M. Pollastri, and I. Principi. 2012. Innovative urban water management as a climate change adaptation strategy: results from the implementation of the project "Water Against Climate Change (WATACLIC)." Water 4(4):1025-1038. https://doi.org/10.3390/w4041025

Davies, B., J. Biggs, P. Williams, M. Whitfield, P. Nicolet, D. Sear, S. Bray, and S. Maund. 2008. Comparative biodiversity of aquatic habitats in the European agricultural landscape. Agriculture, Ecosystems and Environment 125(1-4):1-8. https://doi.org/10.1016/ j.agee.2007.10.006

De Vleeschauwer, K., J. Weustenraad, C. Nolf, V. Wolfs, B. De Meulder, K. Shannon, and P. Willems. 2014. Green-blue water in the city: quantification of impact of source control versus endof-pipe solutions on sewer and river floods. Water Science and Technology 70(11):1825-1837. https://doi.org/10.2166/wst.2014.306

Dietz, M. E. 2007. Low impact development practices: a review of current research and recommendations for future directions. Water, Air, and Soil Pollution 186:351-363. https://doi. org/10.1007/s11270-007-9484-Z

Dobbie, M., and R. Green. 2013. Public perceptions of freshwater wetlands in Victoria, Australia. Landscape and Urban Planning 110:143-154. https://doi.org/10.1016/j.landurbplan.2012.11.003

Dunnett, N., A. Nagase, R. Booth, and P. Grime. 2008. Influence of vegetation composition on runoff in two simulated green roof experiments. Urban Ecosystems 11:385-398. https://doi. org/10.1007/s11252-008-0064-9

European Commission. 2012. Supporting the implementation of green infrastructure: final report. ENV.B.2/SER/2014/0012. Directorate-General for the Environment, European Commission, Brussels. [online] URL: https://ec.europa.eu/environment/nature/ ecosystems/docs/green_infrastructures/GI\%20Final\%20Report.pdf

Fenner, R. 2017. Spatial evaluation of multiple benefits to encourage multi-functional design of sustainable drainage in blue-green cities. Water 9(12):953. https://doi.org/10.3390/ w9120953

Fernandez-Canero, R., and P. Gonzalez-Redondo. 2010. Green roofs as a habitat for birds: a review. Journal of Animal and Veterinary Advances 9(15):2041-2052. https://doi.org/10.3923/ javaa.2010.2041.2052

Francis, R. A. 2011. Wall ecology: a frontier for urban biodiversity and ecological engineering. Progress in Physical Geography: Earth and Environment 35(1):43-63. https://doi.org/10.1177/0309133310385166 
Francis, R. A., and M. A. Chadwick. 2013. Urban ecosystems: understanding the human environment. Routledge, London, UK. https://doi.org/10.4324/9780203133644

Francis, R. A., and J. Lorimer. 2011. Urban reconciliation ecology: the potential of living roofs and walls. Journal of Environmental Management 92(6):1429-1437. https://doi.org/10.1016/ j.jenvman.2011.01.012

Garrard, G. E., N. S. G. Williams, L. Mata, J. Thomas, and S. A. Bekessy. 2018. Biodiversity sensitive urban design. Conservation Letters 11(2):e12411. https://doi.org/10.1111/conl.12411

Goddard, M. A., A. J. Dougill, and T. G. Benton. 2010. Scaling up from gardens: biodiversity conservation in urban environments. Trends in Ecology and Evolution 25(2):90-98. https://doi.org/10.1016/j.tree.2009.07.016

Hamer, A. J., and M. J. McDonnell. 2008. Amphibian ecology and conservation in the urbanising world: a review. Biological Conservation 141(10):2432-2449. https://doi.org/10.1016/j. biocon.2008.07.020

Hamer, A. J., and K. M. Parris. 2011. Local and landscape determinants of amphibian communities in urban ponds. Ecological Applications 21(2):378-390. https://doi.org/10.1890/10-0390.1

Hassall, C. 2014. The ecology and biodiversity of urban ponds. Wiley Interdisciplinary Reviews: Water 1(2):187-206. https://doi. org/10.1002/wat2.1014

Hassall, C., and S. Anderson. 2015. Stormwater ponds can contain comparable biodiversity to unmanaged wetlands in urban areas. Hydrobiologia 745:137-149. https://doi.org/10.1007/ s10750-014-2100-5

Hauck, T. E., and W. W. Weisser. 2015. AAD: animal-aided design. Studio Animal-Aided Design, Berlin, Germany. [online] URL: http://bln-berlin.de/wp-content/uploads/2016/04/Animal-AidedDesign-Broschuere.pdf

Hill, M. J., J. Biggs, I. Thornhill, R. A. Briers, D. G. Gledhill, J. C. White, P. J. Wood, and C. Hassall. 2017. Urban ponds as an aquatic biodiversity resource in modified landscapes. Global Change Biology 23(3):986-999. https://doi.org/10.1111/gcb.13401

Hill, M. J., and P. J. Wood. 2014. The macroinvertebrate biodiversity and conservation value of garden and field ponds along a rural-urban gradient. Fundamental and Applied Limnology 185(1):107-119. https://doi.org/10.1127/fal/2014/0612

Hoang, L., and R. A. Fenner. 2016. System interactions of stormwater management using sustainable urban drainage systems and green infrastructure. Urban Water Journal 13 (7):739-758. https://doi.org/10.1080/1573062X.2015.1036083

Hobbs, R. J., S. Arico, J. Aronson, J. S. Baron, P. Bridgewater, V. A. Cramer, P. R. Epstein, J. J. Ewel, C. A. Klink, A. E. Lugo, D. Norton, D. Ojima, D. M. Richardson, E. W. Sanderson, F. Valladares, M. Vilà, R. Zamora, and M. Zobel. 2006. Novel ecosystems: theoretical and management aspects of the new ecological world order. Global Ecology and Biogeography 15 (1):1-7. https://doi.org/10.1111/j.1466-822X.2006.00212.X
Hobbs, R. J., and L. F. Huenneke. 1992. Disturbance, diversity, and invasion: implications for conservation. Conservation Biology 6(3):324-337. https://doi.org/10.1046/j.1523-1739.1992.06030324. $\underline{\mathrm{x}}$

Holtmann, L., K. Philipp, C. Becke, and T. Fartmann. 2017. Effects of habitat and landscape quality on amphibian assemblages of urban stormwater ponds. Urban Ecosystems 20:1249-1259. https://doi.org/10.1007/s11252-017-0677-y

Holzer, K. A. 2014. Amphibian use of constructed and remnant wetlands in an urban landscape. Urban Ecosystems 17:955-968. https://doi.org/10.1007/s11252-014-0373-0

Ignatieva, M., and K. Ahrné. 2013. Biodiverse green infrastructure for the 21st century: from "green desert" of lawns to biophilic cities. Journal of Architecture and Urbanism 37(1):1-9. https://doi.org/10.3846/20297955.2013.786284

Ignatieva, M., G. H. Stewart, and C. Meurk. 2011. Planning and design of ecological networks in urban areas. Landscape and Ecological Engineering 7:17-25. https://doi.org/10.1007/s11355-010-0143$\mathrm{y}$

Ikin, K., D. S. Le Roux, L. Rayner, N. R. Villaseñor, K. Eyles, P. Gibbons, A. D. Manning, and D. B. Lindenmayer. 2015. Key lessons for achieving biodiversity-sensitive cities and towns. Ecological Management and Restoration 16(3):206-214. https:// doi.org/10.1111/emr.12180

Jeanmougin, M., F. Leprieur, G. Loïs, and P. Clergeau. 2014. Finescale urbanization affects Odonata species diversity in ponds of a megacity (Paris, France). Acta Oecologica 59:26-34. https://doi. org/10.1016/j.actao.2014.05.008

Jim, C. Y., and W. Y. Chen. 2010. Habitat effect on vegetation ecology and occurrence on urban masonry walls. Urban Forestry and Urban Greening 9(3):169-178. https://doi.org/10.1016/j. ufug.2010.02.004

Jurczak, T., A. Wojtal-Frankiewicz, Z. Kaczkowski, Z. Oleksińska, A. Bednarek, and M. Zalewski. 2018. Restoration of a shady urban pond - the pros and cons. Journal of Environmental Management 217:919-928. https://doi.org/10.1016/j.jenvman.2018.03.114

Kazemi, F., S. Beecham, and J. Gibbs. 2009a. Streetscale bioretention basins in Melbourne and their effect on local biodiversity. Ecological Engineering 35(10):1454-1465. https:// doi.org/10.1016/j.ecoleng.2009.06.003

Kazemi, F., S. Beecham, and J. Gibbs. 2011. Streetscape biodiversity and the role of bioretention swales in an Australian urban environment. Landscape and Urban Planning 101 (2):139-148. https://doi.org/10.1016/j.landurbplan.2011.02.006

Kazemi, F., S. Beecham, J. Gibbs, and R. Clay. 2009b. Factors affecting terrestrial invertebrate diversity in bioretention basins in an Australian urban environment. Landscape and Urban Planning 92(3-4):304-313. https://doi.org/10.1016/j. landurbplan.2009.05.014

Kim, J.-H., H. Y. Kim, and F. Demarie. 2017. Facilitators and barriers of applying low impact development practices in urban development. Water Resources Management 31:3795-3808. https://doi.org/10.1007/s11269-017-1707-5 
Köhler, M. 2006. Long-term vegetation research on two extensive green roofs in Berlin. Urban Habitats 4(1):3-26. [online] URL: http://urbanhabitats.org/v04n01/berlin full.html

Köhler, M., and P. H. Poll. 2010. Long-term performance of selected old Berlin greenroofs in comparison to younger extensive greenroofs in Berlin. Ecological Engineering 36(5):722-729. https://doi.org/10.1016/j.ecoleng.2009.12.019

Köhler, M., and M. Schmidt. 1997. Hof- Fassaden und Dachbegrünung: 12 years experience. Landschaftsentwicklung und Umweltforschung 105:1-175.

Kowarik, I. 2011. Novel urban ecosystems, biodiversity, and conservation. Environmental Pollution 159:1974-1983. https://doi. org/10.1016/j.envpol.2011.02.022

Ksiazek, K., J. Fant, and K. Skogen. 2012. An assessment of pollen limitation on Chicago green roofs. Landscape and Urban Planning 107(4):401-408. https://doi.org/10.1016/j.landurbplan.2012.07.008

Kuller, M., P. M. Bach, D. Ramirez-Lovering, and A. Deletic. 2017. Framing water sensitive urban design as part of the urban form: a critical review of tools for best planning practice. Environmental Modelling and Software 96:265-282. https://doi. org/10.1016/j.envsoft.2017.07.003

Kumar, P., editor. 2010. The economics of ecosystems and biodiversity: ecological and economic foundations. Earthscan, London, UK.

Lavorel, S. 2013. Plant functional effects on ecosystem services. Journal of Ecology 101(1):4-8. https://doi.org/10.1111/1365-2745.12031

Lawson, E., C. Thorne, S. Ahilan, D. Allen, S. Arthur, G. Everett, R. Fenner, V. Glenis, D. Guan, L. Hoang, C. Kilsby, J. Lamond, J. Mant, S. Maskrey, N. Mount, A. Sleigh, L. Smith, and N. Wright. 2014. Delivering and evaluating the multiple flood risk benefits in blue-green cities; an interdisciplinary approach. Pages 113-124 in D. Proverbs and C. A. Brebbia, editors. Food recovery, innovation and response IV. WIT Press, Ashurst, UK.

Lenth, B. A., R. L. Knight, and W. C. Gilgert. 2006. Conservation value of clustered housing developments. Conservation Biology 20(5):1445-1456. https://doi.org/10.1111/j.1523-1739.2006.00491. $\underline{\mathrm{x}}$

Lepczyk, C. A., M. F. J. Aronson, K. L. Evans, M. A. Goddard, S. B. Lerman, and J. S. MacIvor. 2017. Biodiversity in the city: fundamental questions for understanding the ecology of urban green spaces for biodiversity conservation. Bioscience 67 (9):799-807. https://doi.org/10.1093/biosci/bix079

Lienert, J., J. Monstadt, and B. Truffer. 2006. Future scenarios for a sustainable water sector: a case study from Switzerland. Environmental Science and Technology 40(2):436-442. https://doi. org/10.1021/es0514139

Lundholm, J., A. Heim, S. Tran, and T. Smith. 2014. Leaf and life history traits predict plant growth in a green roof ecosystem. Plos One 9(6):e101395. https://doi.org/10.1371/journal.pone.0101395

Lundholm, J., J. S. MacIvor, Z. MacDougall, and M. Ranalli. 2010. Plant species and functional group combinations affect green roof ecosystem functions. Plos One 5(3):e9677. https://doi. org/10.1371/journal.pone.0009677
Lundholm, J. T., and N. S. G. Williams. 2015. Effects of vegetation on green roof ecosystem services. Pages 211-232 in R. K. Sutton, editor. Green roof ecosystems. Springer, Cham, Switzerland. https://doi.org/10.1007/978-3-319-14983-7_9

Lundy, L., and R. Wade. 2011. Integrating sciences to sustain urban ecosystem services. Progress in Physical Geography: Earth and Environment 35(5):653-669. https://doi.org/10.1177/0309133311422464

MacIvor, J. S., and K. Ksiazek. 2015. Invertebrates on green roofs. Pages 333-355 in R. K. Sutton, editor. Green roof ecosystems. Springer, Cham, Switzerland. https://doi.org/10.1007/978-3-319$-14983-7 \quad 14$

MacIvor, J. S., and J. Lundholm. 2011. Insect species composition and diversity on intensive green roofs and adjacent level-ground habitats. Urban Ecosystems 14:225-241. https://doi.org/10.1007/ $\underline{\text { s11252-010-0149-0 }}$

MacIvor, J. S., M. A. Ranalli, and J. T. Lundholm. 2011. Performance of dryland and wetland plant species on extensive green roofs. Annals of Botany 107(4):671-679. https://doi. org/10.1093/aob/mcr007

Mackintosh, T., and J. Davis. 2013. The importance of urban wetlands. Pages 2-17 in S. Paul, editor. Workbook for managing urbanized wetlands in Australia. Sydney Olympic Park Authority, Sydney, Australia. [online] URL: https://www.sopa.nsw.gov.au/-/ media/files/sopa/sopa/publications/wet-ebook-workbook-for-managingurban-wetlands-in-australia/101-the-importance-of-urban-wetlands. pdf

Madre, F., A. Vergnes, N. Machon, and P. Clergeau. 2013. A comparison of 3 types of green roof as habitats for arthropods. Ecological Engineering 57:109-117. https://doi.org/10.1016/j. ecoleng.2013.04.029

Madre, F., A. Vergnes, N. Machon, and P. Clergeau. 2014. Green roofs as habitats for wild plant species in urban landscapes: first insights from a large-scale sampling. Landscape and Urban Planning 122:100-107. https://doi.org/10.1016/j.landurbplan.2013.11.012

Maksimovic, C., and J. A. Tejada-Guibert. 2005. Frontiers in urban water management: deadlock or hope. IWA Publishing, London, UK. https://doi.org/10.2166/9781780402659

Mathey, J., S. Rößler, J. Banse, I. Lehmann, and A. Bräuer. 2015. Brownfields as an element of green infrastructure for implementing ecosystem services into urban areas. Journal of Urban Planning and Development 141(3). http://dx.doi. org/10.1061/(ASCE)UP.1943-5444.0000275

Matzinger, A., M. Schmid, C. Strehl, D. Nickel, M. Pallasch, D. Kaiser, C. Möller, D. Leßmann, R. von Tils, I. Säumel, A. Winkler, B. Heinzmann, B. Reichmann, H. Sonnenberg, M. Rehfeld-Klein, and P. Rouault. 2017. Integrated planning of urban stormwater management - introduction to the KURAS-approach from Berlin, Germany. Pages 1881-1887 in Proceedings of the International Congress of Urban Drainage (ICUD). IWA Publishing, London, UK.

Mayrand, F., and P. Clergeau. 2018. Green roofs and green walls for biodiversity conservation: a contribution to urban connectivity? Sustainability 10(4):985. https://doi.org/10.3390/ $\underline{\text { su10040985 }}$ 
McGoff, E., A. G. Solimini, M. T. Pusch, T. Jurca, and L. Sandin. 2013. Does lake habitat alteration and land-use pressure homogenize European littoral macroinvertebrate communities? Journal of Applied Ecology 50(4):1010-1018. https://doi. org/10.1111/1365-2664.12106

Miller, B. P., E. A. Sinclair, M. H. M. Menz, C. P. Elliott, E. Bunn, L. E. Commander, E. Dalziell, E. David, B. Davis, T. E. Erickson, P. J. Golos, S. L. Krauss, W. Lewandrowski, C. E. Mayence, L. Merino-Martín, D. J. Merritt, P. G. Nevill, R. D. Phillips, A. L. Ritchie, S. Ruoss, and J. C. Stevens. 2017. A framework for the practical science necessary to restore sustainable, resilient, and biodiverse ecosystems. Restoration Ecology 25(4):605-617. https://doi.org/10.1111/rec.12475

Mills, L. S., M. E. Soulé, and D. F. Doak. 1993. The keystonespecies concept in ecology and conservation. Bioscience 43 (4):219-224. https://doi.org/10.2307/1312122

Mimouni, E., B. Pinel-Alloul, and B. E. Beisner. 2015. Assessing aquatic biodiversity of zooplankton communities in an urban landscape. Urban Ecosystems 18:1353-1372. https://doi. org/10.1007/s11252-015-0457-5

Montalto, F. A., T. A. Bartrand, A. M. Waldman, K. A. Travaline, C. H. Loomis, C. McAfee, J. M. Geldi, G. J. Riggall, and L. M. Boles. 2013. Decentralised green infrastructure: the importance of stakeholder behaviour in determining spatial and temporal outcomes. Structure and Infrastructure Engineering 9 (12):1187-1205. https://doi.org/10.1080/15732479.2012.671834

Montalto, F., C. Behr, K. Alfredo, M. Wolf, M. Arye, and M. Walsh. 2007. A rapid assessment of the cost-effectiveness of low impact development for CSO control. Landscape and Urban Planning 82(3):117-131. https://doi.org/10.1016/j.landurbplan.2007.02.004

Nagase, A., and M. Nomura. 2014. An evaluation of one example of biotope roof in Japan: plant development and invertebrate colonisation after 8 years. Urban Forestry and Urban Greening 13 (4):714-724. https://doi.org/10.1016/j.ufug.2014.07.004

Nelson, E., G. Mendoza, J. Regetz, S. Polasky, H. Tallis, D. R. Cameron, K. M. A. Chan, G. C. Daily, J. Goldstein, P. M. Kareiva, E. Lonsdorf, R. Naidoo, T. H. Ricketts, and M. R. Shaw. 2009. Modeling multiple ecosystem services, biodiversity conservation, commodity production, and tradeoffs at landscape scales. Frontiers in Ecology and the Environment 7(1):4-11. https://doi. $\underline{\text { org/10.1890/080023 }}$

Nicolet, P., J. Biggs, G. Fox, M. J. Hodson, C. Reynolds, M. Whitfield, and P. Williams. 2004. The wetland plant and macroinvertebrate assemblages of temporary ponds in England and Wales. Biological Conservation 120(2):261-278. https://doi. org/10.1016/j.biocon.2004.03.010

Noble, A., and C. Hassall. 2015. Poor ecological quality of urban ponds in northern England: causes and consequences. Urban Ecosystems 18:649-662. https://doi.org/10.1007/s11252-014-0422-8

Norton, B. A., A. M. Coutts, S. J. Livesley, R. J. Harris, A. M. Hunter, N. S. G. Williams. 2015. Planning for cooler cities: a framework to prioritise green infrastructure to mitigate high temperatures in urban landscapes. Landscape and Urban Planning 134:127-138. https://doi.org/10.1016/j.landurbplan.2014.10.018
O'Brien, C. D. 2015. Sustainable drainage system (SuDS) ponds in Inverness, UK and the favourable conservation status of amphibians. Urban Ecosystems 18:321-331. https://doi. org/10.1007/s11252-014-0397-5

Oberndorfer, E., J. Lundholm, B. Bass, R. R. Coffman, H. Doshi, N. Dunnett, S. Gaffin, M. Köhler, K. K. Y. Liu, and B. Rowe. 2007. Green roofs as urban ecosystems: ecological structures, functions, and services. Bioscience 57(10):823-833. https://doi. org/10.1641/B571005

Oertli, B., D. A. Joye, E. Castella, R. Juge, D. Cambin, and J.-B. Lachavanne. 2002. Does size matter? The relationship between pond area and biodiversity. Biological Conservation 104(1):59-70. https://doi.org/10.1016/S0006-3207(01)00154-9

Palmer, M., E. Bernhardt, E. Chornesky, S. Collins, A. Dobson, C. Duke, B. Gold, R. Jacobson, S. Kingsland, R. Kranz, M. Mappin, M. L. Martínez, F. Micheli, J. Morse, M. Pace, M. Pascual, S. Palumbi, O. J. Reichman, A. Simons, A. Townsend, and M. Turner. 2004. Ecology for a crowded planet. Science 304 (5675):1251-1252. https://doi.org/10.1126/science.1095780

Pascual-Hortal, L., and S. Saura. 2006. Comparison and development of new graph-based landscape connectivity indices: towards the priorization of habitat patches and corridors for conservation. Landscape Ecology 21:959-967. https://doi. org/10.1007/s10980-006-0013-Z

Pearce, H., and C. L. Walters. 2012. Do green roofs provide habitat for bats in urban areas? Acta Chiropterologica 14(2):469-478. https://doi.org/10.3161/150811012X661774

Qiu, Y., B. J. W. Chen, Y. Song, Z. Y. X. Huang, L. Wan, C. Huang, M. Liu, and C. Xu. 2016. Composition, distribution and habitat effects of vascular plants on the vertical surfaces of an ancient city wall. Urban Ecosystems 19:939-948. https://doi.org/10.1007/ $\underline{\mathrm{s} 11252-016-0528-2}$

Roy, A. H., L. K. Rhea, A. L. Mayer, W. D. Shuster, J. J. Beaulieu, M. E. Hopton, M. A. Morrison, and A. St. Amand. 2014. How much is enough? Minimal responses of water quality and stream biota to partial retrofit stormwater management in a suburban neighborhood. Plos One 9(1):e85011. https://doi.org/10.1371/ journal.pone.0085011

Rozos, D., H. D. Skilodimou, C. Loupasakis, and G. D. Bathrellos. 2013. Application of the revised universal soil loss equation model on landslide prevention. An example from N. Euboea (Evia) Island, Greece. Environmental Earth Sciences 70:3255-3266. https://doi.org/10.1007/s12665-013-2390-3

Ruddick, M. 2016. Wild by design: strategies for creating lifeenhancing landscapes. Island Press, Washington, D.C., USA.

Rumble, H., and A. C. Gange. 2013. Soil microarthropod community dynamics in extensive green roofs. Ecological Engineering 57:197-204. https://doi.org/10.1016/j.ecoleng.2013.04.012

Russo, T., K. Alfredo, and J. Fisher. 2014. Sustainable water management in urban, agricultural, and natural systems. Water 6(12)3934-3956. https://doi.org/10.3390/w6123934

Sapkota, M., M. Arora, H. Malano, M. Moglia, A. Sharma, B. George, and F. Pamminger. 2016. An integrated framework for 
assessment of hybrid water supply systems. Water 8(1):4. https:// doi.org/10.3390/w8010004

Säumel, I., F. Weber, and I. Kowarik. 2016. Toward livable and healthy urban streets: roadside vegetation provides ecosystem services where people live and move. Environmental Science and Policy 62:24-33. https://doi.org/10.1016/j.envsci.2015.11.012

Savard, J.-P., P. Clergeau, and G. Mennechez. 2000. Biodiversity concepts and urban ecosystems. Landscape and Urban Planning 48(3-4):131-142. https://doi.org/10.1016/S0169-2046(00)00037-2

Schindler, B. Y., A. B. Griffith, and K. N. Jones. 2011. Factors influencing arthropod diversity on green roofs. Cities and the Environment (CATE) 4(1):5. [online] URL: http://digitalcommons. $\underline{\text { lmu.edu/cate/vol4/iss } 1 / 5}$

Schrader, S., and M. Böning. 2006. Soil formation on green roofs and its contribution to urban biodiversity with emphasis on Collembolans. Pedobiologia 50(4):347-356. https://doi.org/10.1016/ j.pedobi.2006.06.003

Senatsverwaltung für Stadtentwicklung und Umwelt, editor. 2014. Business in Berlin supports biodiversity: recommendations for action - a guide. Senate Department for Urban Development and the Environment, Berlin, Germany. [online] URL: http:// www.globalnature.org/bausteine.net/f/8216/Leitfaden BiologischeVielfalt_englisch.pdf? $\mathrm{fd}=0$

Shamseer, L., D. Moher, M. Clarke, D. Ghersi, A. Liberati, M. Petticrew, P. Shekelle, and L. A. Stewart. 2015. Preferred reporting items for systematic review and meta-analysis protocols (PRISMA-P) 2015: elaboration and explanation. BMJ 349: g7647. https://doi.org/10.1136/bmj.g7647

Shochat, E., S. B. Lerman, J. M. Anderies, P. S. Warren, S. H. Faeth, and C. H. Nilon. 2010. Invasion, competition, and biodiversity loss in urban ecosystems. Bioscience 60(3):199-208. https://doi.org/10.1525/bio.2010.60.3.6

Sievers, M., K. M. Parris, S. E. Swearer, and R. Hale. 2018. Stormwater wetlands can function as ecological traps for urban frogs. Ecological Applications 28(4):1106-1115. https://doi. org/10.1002/eap.1714

Thornhill, I. A. G. 2012. Water quality, biodiversity and ecosystem functioning in ponds across an urban land-use gradient in Birmingham, U.K. Dissertation. University of Birmingham, Birmingham, UK. [online] URL: https://core.ac.uk/download/ pdf/16292741.pdf

Thornhill, I., L. Batty, R. G. Death, N. R. Friberg, and M. E. Ledger. 2017. Local and landscape scale determinants of macroinvertebrate assemblages and their conservation value in ponds across an urban land-use gradient. Biodiversity and Conservation 26:1065-1086. https://doi.org/10.1007/s10531-016-1286-4

Thuring, C., and G. Grant. 2016. The biodiversity of temperate extensive green roofs - a review of research and practice. Israel Journal of Ecology and Evolution 62(1-2):44-57. https://doi. org/10.1080/15659801.2015.1091190

Tonietto, R., J. Fant, J. Ascher, K. Ellis, and D. Larkin. 2011. A comparison of bee communities of Chicago green roofs, parks and prairies. Landscape and Urban Planning 103(1):102-108. https://doi.org/10.1016/j.landurbplan.2011.07.004

van Leeuwen, C. J., J. Frijns, A. van Wezel, and F. H. M. van de Ven. 2012. City blueprints: 24 indicators to assess the sustainability of the urban water cycle. Water Resources Management 26:2177-2197. https://doi.org/10.1007/s11269-012-0009-1

Van Mechelen, C., T. Dutoit, and M. Hermy. 2015a. Vegetation development on different extensive green roof types in a Mediterranean and temperate maritime climate. Ecological Engineering 82:571-582. https://doi.org/10.1016/j.ecoleng.2015.05.011

Van Mechelen, C., K. Van Meerbeek, T. Dutoit, and M. Hermy. 2015b. Functional diversity as a framework for novel ecosystem design: the example of extensive green roofs. Landscape and Urban Planning 136:165-173. https://doi.org/10.1016/j.landurbplan.2014.11.022

Vermonden, K., R. S. E. W. Leuven, G. van der Velde, M. M. van Katwijk, J. G. M. Roelofs, and A. J. Hendriks. 2009. Urban drainage systems: an undervalued habitat for aquatic macroinvertebrates. Biological Conservation 142(5):1105-1115. https://doi.org/10.1016/j.biocon.2009.01.026

Voskamp, I. M., and F. H. M. Van de Ven. 2015. Planning support system for climate adaptation: composing effective sets of bluegreen measures to reduce urban vulnerability to extreme weather events. Building and Environment 83:159-167. https://doi. org/10.1016/j.buildenv.2014.07.018

Walker, E. A., and J. T. Lundholm. 2018. Designed habitat heterogeneity on green roofs increases seedling survival but not plant species diversity. Journal of Applied Ecology 55(2):694-704. https://doi.org/10.1111/1365-2664.12970

Weber, F., I. Kowarik, and I. Säumel. 2014. A walk on the wild side: perceptions of roadside vegetation beyond trees. Urban Forestry and Urban Greening 13(2):205-212. https://doi. org/10.1016/j.ufug.2013.10.010

Williams, N. S. G., J. Lundholm, and J. S. MacIvor. 2014. FORUM: Do green roofs help urban biodiversity conservation? Journal of Applied Ecology 51(6):1643-1649. https://doi. org/10.1111/1365-2664.12333

Yalcinalp, E., S. Ozveren, A. Meral, M. Pulatkan, and S. Akbulut. 2017. Habitat effect on urban roof vegetation. Sustainability 9 (11):1985. https://doi.org/10.3390/su9111985 
APPENDIX 1. Appendix A: Keywords relating to urban water management measures (A) and outcome-related key words for habitat services (B). Keywords relate to TEEB (2010) classification of ecosystem services. The terms shown in column "Keywords" were inserted in the Web of Science search engine combined by 'AND' with keywords for different urban water management measures (A).

Appendix A: Keywords relating to urban water management measures (A) and outcome-related key words for habitat services (B). Keywords relate to TEEB (2010) classification of ecosystem services. The terms shown in column "Keywords" were inserted in the Web of Science search engine combined by 'AND' with keywords for different urban water management measures (A). Numbers of paper per measure $(\mathrm{C})$.

Search for :

A) Urban rainwater management measures

B) Biodiversity effects and Habitat Services of urban water management measures

\author{
Urban * Green roof \\ Urban * Green Facade \\ Urban * Ponds \\ Urban * Swales \\ Urban * Rain Gardens \\ Permeable pavement
}

\section{Keywords}

Vegetated roofs; roof gardens, living roofs, ecoroof, brown roof, turf roof, sod roof Green Walls; Vertical greening systems, living walls, vegetated wall

Bioretention basin, bioswale, Bioretention areas, bioretention cell depavement of impervious area, pervious pavement

Biodiversity effects and Habitat services Biodiversity, species; habitat; Biodiversity maintenance, gene pool protection, nursery service; corridor

C) Number of papers per measure

\begin{tabular}{|c|c|c|c|c|c|c|c|}
\hline$x_{0}$ & Green roofs & Green walls & Swales & $\begin{array}{l}\text { Rain } \\
\text { gardens }\end{array}$ & $\begin{array}{l}\text { Pervious } \\
\text { pavement }\end{array}$ & Ponds & Total \\
\hline Total results & 236 & 124 & 32 & 57 & 19 & 430 & 830 \\
\hline Results with filter & 99 & 25 & 11 & 18 & 6 & 153 & 300 \\
\hline Selected articles & 72 & 10 & 7 & 4 & 4 & 85 & 182 \\
\hline Available articles & 47 & 8 & 7 & 2 & 4 & 72 & 140 \\
\hline Articles used in the table & 73 & 15 & 7 & 0 & 0 & 67 & 164 \\
\hline Articles from other sources & 26 & 7 & 0 & 0 & 0 & 32 & 65 \\
\hline Reviews & 9 & 2 & 1 & 0 & 2 & 10 & 25 \\
\hline Reviews selected and screened & 4 & 1 & 1 & 0 & 1 & 5 & 12 \\
\hline
\end{tabular}


APPENDIX 2. Appendix B Reference lists for Table 1 on synthesis of habitat services provided by different rainwater management (RWM) measures.

Appendix B: Reference lists for Table 1 on synthesis of habitat services provided by different rainwater management (RWM) measures

1. Ackley, J. W., and P. A. Meylan. 2010. Watersnake Eden: use of stormwater retention ponds by mangrove salt marsh snakes (Nerodiaclarkiicompressicauda) in urban Florida. Herpetological Conservation and Biology 5: 17-22.2. Aloisio, J. M., M. I. Palmer, M. A. Giampieri, A. R. Tuininga, and J. D. Lewis. 2017. Spatially dependent biotic and abiotic factors drive survivorship and physical structure of green roof vegetation. Ecological Applications 27:297-308. https://doi.org/10.1002/ eap.14443. ApindaLegnouo, E. A., M. J. Samways, J. P. Simaika. 2014. Value of artificial ponds for aquatic beetle and bug conservation in the Cape Floristic Region biodiversity hotspot. Aquatic Conservation: Marine and Freshwater Ecosystems 24: 522-535. https://doi.org/10.1002/aqc.24134. Bates, A. J., J. P. Sadler, R. Mackay. 2013. Vegetation development over four years on two green roofs in the UK. Urban Forestry \& Urban Greening 12:98-108. https://doi.org/10.1016/j.ufug.2012.12.0035. Baumann, N. 2006. Ground-Nesting Birds on Green Roofs in Switzerland: Preliminary Observations. Urban Habitats 4 (1): 37-516. Baumann, N., and F. Kasten. 2010. Green roofs-urban habitats forground-nesting birds and plants. Urban Biodiversity and Design(eds N.Muller, P. Werner \& J.G. Kelcy). Blackwell Publishing Ltd. pp. 348-362. Oxford.7. Baxter, C.V., K. D. Fausch, and W. Carl Saudners. 2005. Tangled webs: reciprocal flows of invertebrate prey link streams and riparian zones. Freshwater Biology 50: 201-220. https://doi.org/10.1111/j.1365-2427.2004.01328.x8. Benvenuti, S. 2014. Wildflower green roofs for urban landscaping, ecological sustainability and biodiversity. Landscape and Urban Planning 124: 151-161. https://doi. org/10.1016/j.landurbplan.2014.01.0049. Benvenuti, S., V. Malandrin, and A. Pardossi. 2016. Germination ecology of wild living walls for sustainable vertical garden in urban environment. Scientia Horticulturae 203: 185-191. https://doi.org/10.1016/j. scienta.2016.03.031Blakely, T. J., J. S. Harding, A. R. Mcintosh, and M. J. Winterbourn. 2006. Barriers to the recovery of

aquatic insect communities in urban streams. FreshwaterBiology 51: 10. Ackley, J. W., and P. A. Meylan. 2010. Watersnake Eden: use of stormwater retention ponds by mangrove salt marsh snakes (Nerodiaclarkiicompressicauda) in urban Florida.

Herpetological Conservation and Biology 5: 17-22.4-1645. https://doi.org/10.1111/j.1365-2427.2006.01601.x11. Blank, L., A. Vasl, B. Y. Schindler, G. J. Kadas, and L. Blaustein. 2017. Horizontal and vertical island biogeography of arthropods on green roofs: a review. Urban Ecosystems 20: 911-917. https://doi.org/10.1007/s11252-016-0639-912. Blaustein, J., A. Sadeh, and L. Blaustein. 2014. Influence of fire salamander larvae on among-pool distribution of mosquito egg rafts: oviposition habitat selection or egg raft predation? Hydrobiologia 723: 157-165. https://doi.org/10.1007/s10750-013-1554-113. Blicharska, M., J. Andersson, J. Bergsten, U. Bjelke, T. Hilding-Rydevik, and F. Johansson. 2016. Effects of management intensity, function and vegetation on the biodiversity in urban ponds. Urban Forestry \& Urban Greening 20: 103-112. https://doi.org/10.1016/j. ufug.2016.08.01214. Braaker, S., J. Ghazoul, M. K. Obrist, and M. Moretti. 2014. Habitat connectivity shapes urban arthropod communities: the key role of green roofs. Ecology 95: 1010-1021. https://doi.org/10.1890/13-0705.115. Braaker, S., M. K. Obrist, J. Ghazoul, and M. Moretti. 2017. Habitat connectivity and local conditions shape taxonomic and functional diversity of arthropods on green roofs. Journal of Animal Ecology 86: 521-531. https://doi.org/10.1111/1365-2656.1264816. Brand, A. B., and J. W. Snodgrass, 2010. Value of Artificial Habitats for Amphibian Reproduction in Altered Landscapes. Conservation Biology 24: 295-301. https://doi.org/10.1111/j.1523-1739.2009.01301.x17. Brenneisen, S. 2006. Space for urban wildlife: designing green roofs as habitats in Switzerland. Urban Habitats 4(1): 27-3618. Briers, R.A. 2014. Invertebrate Communities and Environmental Conditions in a Series of Urban Drainage Ponds in Eastern Scotland: Implications for Biodiversity and Conservation Value of SUDS. CLEAN - Soil, Air, Water 42: 193-200. https://doi.org/10.1002/clen.20130016219. Burdíková, Z., M. Čapek, Z. !vindrych, M. Gryndler, L. Kubínová, and K. Holcová. 2012. Ecology of Testate Amoebae in the Komořany Ponds in the Vltava Basin. Microbial Ecology 64: 117-130. https://doi.org/10.1007/s00248-011-0003-920. Butler, C., E. Butler, and C. M. Orians. 2012. Native plant enthusiasm reaches new heights: Perceptions, evidence, and the future of green roofs. Urban Forestry \& Urban Greening 11: 1-10. https://doi.org/10.1016/j.ufug.2011.11.00221. Buttschardt, T. 2005. Long-term development of extensive green roofs:Are they suitable as permanent habitat for soil meso- and macrofaunal. International Green Roof Congress 189-198.22. Cameron, R. W. F., J. E. Taylor, and M. R. Emmett. 2014. What's "cool" in the world of green façades? How plant choice influences the cooling properties of green walls. Building and Environment 73: 198-207. https:// doi.org/10.1016/j.buildenv.2013.12.00523. Cao, C. T. N., C. Farrell, P. E. Kristiansen, and J. P. Rayner. 2014. Biochar makes green roof substrates lighter and improves water supply to plants. Ecological Engineering 71: 368-374. https://doi.org/10.1016/j. ecoleng.2014.06.01724. Catalano, C., C. Marcenò, V. A. Laudicina, and R. Guarino. 2016. Thirty years unmanaged green roofs: Ecological research and design implications. Landscape and Urban Planning 149: 11-19. https://doi.org/10.1016/j. landurbplan.2016.01.00325. Cayrou, J., and R. Céréghino. 2005. Life-cycle phenology of some aquatic insects: implications for pond conservation. Aquatic Conservation: Marine and Freshwater Ecosystems 15: 559-571. https://doi.org/10.1002/aqc.73926. Céréghino, R., D. Boix, H. M. Cauchie, K. Martens, and B. Oertli. 2014. The ecological role of ponds in a changing world. Hydrobiologia 723: 1-6. https://doi.org/10.1007/s10750-013-1719-y27. Céréghino, R., A. Ruggiero, P. Marty, and S. Angélibert. 2008. Biodiversity and distribution patterns of freshwater invertebrates in farm ponds of a south-western French agricultural landscape. Hydrobiologia 597: 43-51. https://doi.org/10.1007/s10750-007-9219-628. Charlesworth, S. M., E. Nnadi, O. Oyelola, J. Bennett, F. Warwick, R. Jackson, and D. Lawson. 2012. Laboratory based experiments to assess the use of green and food based compost to improve water quality in a Sustainable Drainage (SUDS) device such as a swale. Science of The Total 
Environment 424: 337-343. https://doi.org/10.1016/j.scitotenv.2012.02.07529. Chester, E. T., and B. J. Robson. 2013. Anthropogenic refuges for freshwater biodiversity: Their ecological characteristics and management. Biological Conservation 166: 64-75. https://doi.org/10.1016/j.biocon.2013.06.01630. Chiquet, C., J. W. Dover, and P. Mitchell. 2013. Birds and the urban environment: the value of green walls. Urban Ecosystems 16: 453-462. https://doi.org/10.1007/s11252-012-0277-931. Clements, R., L. P. Koh, T. M. Lee, R. Meier, and D. Li. 2006. Importance of reservoirs for the conservation of freshwater molluscs in a tropical urban landscape. Biological Conservation 128: 136-146. https://doi.org/10.1016/j.biocon.2005.09.02332. Colla, S., E. Willis, and L. Packer. 2009. Can green roofs provide habitat for urban bees (Hymenoptera: Apidae)? Cities and the Environment 2(1): 4. https://doi.org/10.15365/cate.214200933. Cook-Patton, S. C., and T. L. Bauerle. 2012. Potential benefits of plant diversity on vegetated roofs: A literature review. Journal of Environmental Management 106: 85-92. https://doi.org/10.1016/j. jenvman.2012.04.00334. Dalal, A., and S. Gupta. 2014. Aquatic insect diversity in two temple ponds of Silchar, Assam, N.E. India and their conservation values. Knowledge and Management of Aquatic Ecosystem 415: 9. https://doi.org/10.1051/ kmae/201403535. Dalbeck, L., and K. Weinberg. 2009. Artificial ponds: a substitute for natural Beaver ponds in a Central European Highland (Eifel, Germany)? Hydrobiologia 630: 49-62. https://doi.org/10.1007/s10750-009-9779-836. Darlington A. 1981. Ecology of Walls. Heinemann. Pp. 138. London.37. Davies, R. 2012. Landscapes for life (Stage 2) - An investigation of opportunities for aesthetic improvement and biodiversity enhancement for living roofs in New Zealand [Unpublished Unitec Research Committee Research Report]38. Davies, B., J. Biggs, P. Williams, M. Whitfield, P. Nicolet, D. Sear, S. Bray, and S. Maund. 2008. Comparative biodiversity of aquatic habitats in the European agricultural landscape. Agriculture, Ecosystems \& Environment 125: 1-8. https://doi.org/10.1016/j.agee.2007.10.00639. De Andrade, E. V. E., I. J. L. Palhas, and G. J. B. de Moura. 2014. Diurnal habitat segregation by tadpoles in two temporary ponds in an Atlantic Rainforest remnant, Northeastern Brazil. Hydrobiologia 723: 181-194. https://doi.org/10.1007/s10750-013-1645-z40. De Marco, P., D. S. Nogueira, C. C. Correa, T. B. Vieira, K. D. Silva, N. S. Pinto, D. Bichsel, A. S. V. Hirota, R. R. S. Vieira, F. M. Carneiro, A. A. B. de Oliveira, P. Carvalho, R.P. Bastos, C. Ilg, and B. Oertli. 2014. Patterns in the organization of Cerrado pond biodiversity in Brazilian pasture landscapes. Hydrobiologia 723: 87-101. https://doi.org/10.1007/s10750-013-1695-241. Declerck, S., T. De Bie, D. Ercken, H. Hampel, S. Schrijvers, J. Van Wichelen, V. Gillard, R. Mandiki, B. Losson, D. Bauwens, S. Keijers, W. Wyverman, B. Goddeeris, L. De meester, L. Brendonck, and K. Martens. 2006. Ecological characteristics of small farmland ponds: Associations with land use practices at multiple spatial scales. Biological Conservation 131: 523-532. https://doi.org/10.1016/j. biocon.2006.02.02442. Deng, H., and C. Y. Jim. 2017. Spontaneous plant colonization and bird visits of tropical extensive green roof. Urban Ecosystems 20: 337-352. https://doi.org/10.1007/s11252-016-0596-343. Dézerald, O., S. Talaga, C. Leroy, J. F. Carrias, B. Corbara, A. Dejean, and R. Céréghino. 2014. Environmental determinants of macroinvertebrate diversity in small water bodies: insights from tank-bromeliads. Hydrobiologia 723: 77-86. https://doi.org/10.1007/s10750-013-1464-244. Dunnett, N., and N. Kingsbury. 2008. Planting green roofs and living walls. Timber Press. Portland, Oregon, USA.45. Dunnett, N., A. Nagase, R. Booth, and P. Grime. 2008. Influence of vegetation composition on runoff in two simulated green roof experiments. Urban Ecosystems 11: 385-398. https://doi.org/10.1007/s11252-008-0064-946. Dusza, Y., S. Barot, Y. Kraepiel, J. C. Lata, L. Abbadie, and X. Raynaud. 2017. Multifunctionality is affected by interactions between green roof plant species, substrate depth, and substrate type. Ecology and Evolution 7: 2357-2369. https://doi.org/10.1002/ece3.269147. Eakin, C. J., H. Campa, D. W. Linden, G. J. Roloff, D. B. Rowe, and J. Westphal. 2015. Avian response to green roofs in urban landscapes in the Midwestern USA. Wildlife Society Bulletin 39: 574-582. https://doi.org/10.1002/wsb.56648. Ejsmont-Karabin, J., and N. Kuczyńska-Kippen. 2001. Urban rotifers: structure and densities of rotifer communities in water bodies of the Poznań agglomeration area (western Poland). L. Sanoamuang, H. Segers, R. J. Shiel, and R. D. Gulati (Eds.) Rotifera IX: Proceedings of the IXth International Rotifer Symposium. KhonKaen, Thailand. 16-23 January 2000. Springer Netherlands, Dordrecht. pp. 165-171. https://doi.org/10.1007/978-94-010-0756-6 2349. Fernandez, R., and P. Gonzalez R. 2010. Green Roofs as a Habitat for Birds: A Review. Journal of Animal and Veterinary Advances 9(15):2041-2052. https://doi.org/10.3923/ javaa.2010.2041.205250. Foltz, S. J., and S. I. Dodson. 2009. Aquatic Hemiptera community structure in stormwater retention ponds: a watershed land cover approach. Hydrobiologia 621: 49-62. https://doi.org/10.1007/s10750-008-9631-651.

Fontanarrosa, M. S., M. B. Collantes, and A. O. Bachmann. 2013. Aquatic Insect Assemblages of Man-Made Permanent Ponds, Buenos Aires City, Argentina. Neotropical Entomology 42: 22-31. https://doi.org/10.1007/s13744-012-0093-152. Francis, R. A. 2010. Wall ecology: A frontier for urban biodiversity and ecological engineering. Progress in Physical Geography 35: 43-63. https://doi.org/10.1177/030913331038516653. Francis, R. A., and S. P. G. Hoggart. 2009. Urban river wall habitat and vegetation: Observations from the River Thames through central London. Urban Ecosystems 12: 468-48554. Francis, R. A., and J. Lorimer. 2011. Urban reconciliation ecology: The potential of living roofs and walls. Journal of Environmental Management 92: 1429-1437. https://doi.org/10.1016/j.jenvman.2011.01.012Francis, R., and M. Chadwick. 2013. Urban

Ecosystems: Understanding the Human Environment. Taylor and Francis. London, UK. DOI: 10.4324/978020355. Francis, R. A., and S. P. G. Hoggart. 2009. Urban river wall habitat and vegetation: Observations from the River Thames through central London. Urban Ecosystems 12: 468-4854Fuyuki, A., Y. Yamaura, Y. Nakajima, N. Ishiyama, T. Akasaka, and F. Nakamura. 2014. Pond area and distance from continuous forests affect amphibian egg distributions in urban green spaces: A case study in Sapporo, Japan. Urban Forestry \& Urban Greening 13: 397-56. Aloisio, J. M., M. I. Palmer, M. A. Giampieri, A. R. Tuininga, and J. D. Lewis. 2017. Spatially dependent biotic and abiotic factors drive survivorship and physical structure of green roof vegetation. Ecological Applications 27:297-308. https://doi.org/10.1002/eap.1444. https://doi.org/10.1016/j.ufug.2013.11.00357. Gaston, K. J., R. M. Smith, K. Thompson, and P. H. Warren. 2005. Urban domestic gardens (II): experimental tests of methods for increasing biodiversity. Biodiversity \& Conservation 14 :395. https://doi.org/10.1007/s10531-004-6066-x58. Gayet, 
G., G. Matthieu, P. Defos du Rau, and P. Grillas. 2013. Effects of mute swans on wetlands: a synthesis. Hydrobiologia 723:195-204 doi:10.1007/s10750-013-1704-5.59. Gedge, D., and G. Kadas. 2005. Green roofs and biodiversity. Biologist 52:1-9.60. Gledhill, D. G., and P. James. 2012. Socio-economic variables as indicators of pond conservation value in an urban landscape. Urban Ecosystems 15: 849-861. https://doi.org/10.1007/s11252-012-0242-761. Gledhill, D. G., P. James, and D. H. Davies. 2008. Pond density as a determinant of aquatic species richness in an urban landscape. Landscape Ecology 23: 1219-1230. https://doi.org/10.1007/s10980-008-9292-x62. Goertzen, D., and F. Suhling. 2013. Promoting dragonfly diversity in cities: major determinants and implications for urban pond design. Journal of Insect Conservation 17: 399-409. https://doi. org/10.1007/s10841-012-9522-z63. Graceson, A., J. Monaghan, N. Hall, and M. Hare. 2014. Plant growth responses to different growing media for green roofs. Ecological Engineering 69: 196-200. https://doi.org/10.1016/j.ecoleng.2014.03.06764. Guderyahn, L. B., A. P. Smithers, and M. C. Mims. 2016. Assessing habitat requirements of pond-breeding amphibians in a highly urbanized landscape: implications for management. Urban Ecosystems 19: 1801-1821. https://doi.org/10.1007/ s11252-016-0569-665. Gwak, J. H., B. K. Lee, W. K. Lee, and S. Y. Sohn. 2017. Optimal location selection for the installation of urban green roofs considering honeybee habitats along with socio-economic and environmental effects. Journal of Environmental Management 189: 125-133. https://doi.org/10.1016/j.jenvman.2016.12.02266. Hale, R., R. Coleman, V. Pettigrove, and S. E. Swearer. 2015. REVIEW: Identifying, preventing and mitigating ecological traps to improve the management of urban aquatic ecosystems. Journal of Applied Ecology 52: 928-939. https://doi.org/10.1111/1365-2664.1245867. Hamer, A. J., P. J. Smith, and M. J. McDonnell. 2012. The importance of habitat design and aquatic connectivity in amphibian use of urban stormwater retention ponds. Urban Ecosystems 15: 451-471. https://doi.org/10.1007/s11252-011-0212-568. Hassall, C. 2014. The ecology and biodiversity of urban ponds. Wiley Interdisciplinary Reviews: Water 1: 187-206. https://doi. org/10.1002/wat2.101469. Hassall, C., and S. Anderson. 2015. Stormwater ponds can contain comparable biodiversity to unmanaged wetlands in urban areas. Hydrobiologia 745: 137-149. https://doi.org/10.1007/s10750-014-2100-570. Heim, A., and J. Lundholm. 2014a. The effects of substrate depth heterogeneity on plant species coexistence on an extensive green roof. Ecological Engineering 68: 184-188. https://doi.org/10.1016/j.ecoleng.2014.03.02371. Heim, A., and J. Lundholm. 2014 b. Species interactions in green roof vegetation suggest complementary planting mixtures. Landscape and Urban Planning 130: 125-133. https://doi.org/10.1016/j.landurbplan.2014.07.00772. Heim, A., J. Lundholm, and L. Philip. 2014. The impact of mosses on the growth of neighbouring vascular plants, substrate temperature and evapotranspiration on an extensive green roof. Urban Ecosystems 17: 1119-1133. https://doi.org/10.1007/s11252-014-0367-y73. Heino, J., L. M. Bini, J. Andersson, J. Bergsten, U. Bjelke, and F. Johansson. 2017. Unravelling the correlates of species richness and ecological uniqueness in a metacommunity of urban pond insects. Ecological Indicators 73: 422-431. https://doi.org/10.1016/j.ecolind.2016.10.00674. Herrmann, J. 2012. Chemical and biological benefits in a stormwater wetland in Kalmar, SE Sweden. Limnologica - Ecology and Management of Inland Waters 42: 299-309. https://doi.org/10.1016/j.limno.2012.07.00375. Hill, M., and P. Wood. 2014. The macroinvertebrate biodiversity and conservation value of garden and field ponds along a rural-urban gradient. Fundamental and Applied Limnology / Archiv für Hydrobiologie 185(1) https://doi.org/10.1127/fal/2014/061276. Hill, M. J., J. Biggs, I. Thornhill, R. A. Briers, D. G. Gledhill, J. C. White, P. J. Wood, and C. Hassall. 2017. Urban ponds as an aquatic biodiversity resource in modified landscapes. Global Change Biology 23: 986-999. https://doi.org/10.1111/gcb.1340177. Hill, M. J., D. B. Ryves, J. C. White, and P. J. Wood. 2016. Macroinvertebrate diversity in urban and rural ponds: Implications for freshwater biodiversity conservation. Biological Conservation 201: 50-59. https://doi.org/10.1016/j.biocon.2016.06.02778. Hitchings, S. P., and T. J. C. Beebee. 1997. Genetic substructuring as a result of barriers to gene flow in urban Rana temporaria (common frog) populations: implications for biodiversity conservation. Heredity 79: 117-12779. Hitchmough, J., and M. Wagner. 2013. The dynamics of designed plant communities of rosette forming forbs for use in supra-urban drainage swales. Landscape and Urban Planning 117: 122-134. https://doi.org/10.1016/j.landurbplan.2013.04.01880. Holtmann, L., K. Philipp, C. Becke, and T. Fartmann. 2017. Effects of habitat and landscape quality on amphibian assemblages of urban stormwater ponds. Urban Ecosystems 20: 1249-1259. https://doi.org/10.1007/s11252-017-0677-y81. Holzer, K. A. 2014. Amphibian use of constructed and remnant wetlands in an urban landscape. Urban Ecosystems 17: 955-968. https://doi.org/10.1007/s11252-014-0373-082. Hunter, A. M., N. S. G Williams, J. P. Rayner, L. Aye, D. Hes, and S. J. Livesley. 2014. Quantifying the thermal performance of green façades: A critical review. Ecological Engineering 63: 102-113. https://doi.org/10.1016/j.ecoleng.2013.12.02183. Ishimatsu, K., and K. Ito. 2013. Brown/biodiverse roofs: a conservation action for threatened brownfields to support urban biodiversity. Landscape and Ecological Engineering 9: 299-304. https://doi.org/10.1007/s11355-011-0186-884. Jeanmougin, M., F. Leprieur, G. Loïs, and P. Clergeau. 2014. Fine-scale urbanization affects Odonata species diversity in ponds of a megacity (Paris, France). Acta Oecologica 59: 26-34. https://doi.org/10.1016/j.actao.2014.05.00885. Jim, C. 2010. Ecological Design of Sky Woodland in Compact Urban Hong Kong. Greening Rooftops for Sustainable Communities, p. 1-15. Baltimore: Green Roofs for Healthy Cities, 2008.86. Jim, C. Y., and W. Y. Chen. 2010. Habitat effect on vegetation ecology and occurrence on urban masonry walls. Urban Forestry \& Urban Greening 9: 169-178. https://doi.org/10.1016/j.ufug.2010.02.00487. Kadas, G. 2006. Rare Invertebrates Colonizing Green Roofs in London. Urban Habitats 4(1): 62-83.88. Karraker, N. E., J. P. Gibbs, and J. R. Vonesh. 2008. Impacts of road de-icing salt on the demography of vernal pool-breeding amphibians. Ecological Applications 18: 724-734. https://doi.org/10.1890/07-1644.189. Kazemi, F., S. Beecham, and J. Gibbs. 2011. Streetscape biodiversity and the role of bioretention swales in an Australian urban environment. Landscape and Urban Planning 101: 139-148. https://doi. org/10.1016/j.landurbplan.2011.02.00690. Kazemi, F., S. Beecham, and J. Gibbs. 2009a. Streetscale bioretention basins in Melbourne and their effect on local biodiversity. Ecological Engineering 35: 1454-1465. https://doi.org/10.1016/j.

ecoleng.2009.06.00391. Kazemi, F., S. Beecham, J. Gibbs, and R. Clay. 2009b. Factors affecting terrestrial invertebrate diversity 
in bioretention basins in an Australian urban environment. Landscape and Urban Planning 92: 304-313. https://doi.org/10.1016/ j.landurbplan.2009.05.01492. Köhler, M. 2008. Green facades - a view back and some visions. Urban Ecosystems 11:423-43693. Köhler, M. 2006. Long-term Vegetation Research on Two Extensive Green roofs in Berlin. Urban Habitats 4(1): 3-26.94. Köhler, M., and P. H. Poll. 2010. Long-term performance of selected old Berlin greenroofs in comparison to younger extensive greenroofs in Berlin. Ecological Engineering 36: 722-729. https://doi.org/10.1016/j.ecoleng.2009.12.01995. Ksiazek, K., J. Fant, and K. Skogen. 2012. An assessment of pollen limitation on Chicago green roofs. Landscape and Urban Planning 107: $401-408$. https://doi.org/10.1016/j.landurbplan.2012.07.00896. Lisci M., M. Monte, and E. Pacini. 2003. Lichens and higher plants on stone: a review. International Biodeterioration and Biodegradtion 51(1):1-17.Le Viol, I., J. Mocq, R. Julliard, and C. Kerbiriou.

2009. The contribution of motorway stormwater retention ponds to the biodiversity of aquatic macroinvertebrates. Biological

Conservation 142: 397. Ackley, J. W., and P. A. Meylan. 2010. Watersnake Eden: use of stormwater retention ponds by mangrove salt marsh snakes (Nerodiaclarkiicompressicauda) in urban Florida. Herpetological Conservation and Biology 5: 17-22.-3171.

https://doi.org/10.1016/j.biocon.2009.08.01898. Lundholm, J., A. Heim, S. Tran, and T. Smith. 2014. Leaf and Life History Traits Predict Plant Growth in a Green Roof Ecosystem. PLoS ONE 9. e101395. https://doi.org/10.1371/journal.pone.010139599. Lundholm, J., J. S. MacIvor, Z. MacDougall, and M. Ranalli. 2010. Plant Species and Functional Group Combinations Affect Green Roof Ecosystem Functions. PLoS ONE 5. e9677. https://doi.org/10.1371/journal.pone.0009677100. Lundholm, J. T. 2016. Spontaneous dynamics and wild design in green roofs. Israel Journal of Ecology \& Evolution 62: 23-31. https://doi. org/10.1080/15659801.2015.1025511101. MacIvor, J. S., and K. Ksiazek. 2015. In: Sutton R. (eds) Green Roof Ecosystems. Ecological Studies (Analysis and Synthesis), vol 223. Springer, Cham. pp. 333-355. https://doi. org/10.1007/978-3-319-14983-7 14102. MacIvor, J. S., and J. Lundholm. 2011. Insect species composition and diversity on intensive green roofs and adjacent level-ground habitats. Urban Ecosystems 14: 225-241. https://doi.org/10.1007/ s11252-010-0149-0103. MacIvor, J. S., M. A. Ranalli, and J. T. Lundholm. 2011. Performance of dryland and wetland plant species on extensive green roofs. Annals of Botany 107: 671-679. https://doi.org/10.1093/aob/mcr007104. Madre, F., A. Vergnes, N. Machon, and P. Clergeau. 2014. Green roofs as habitats for wild plant species in urban landscapes: First insights from a large-scale sampling. Landscape and Urban Planning 122: 100-107. https://doi.org/10.1016/j.landurbplan.2013.11.012105. Madre, F., A. Vergnes, N. Machon, and P. Clergeau. 2013. A comparison of 3 types of green roof as habitats for arthropods. Ecological Engineering 57: 109-117. https://doi.org/10.1016/j.ecoleng.2013.04.029106. Mak, C., M. Scholz, and P. James. 2017. Sustainable drainage system site assessment method using urban ecosystem services. Urban Ecosystems 20: 293-307. https://doi. org/10.1007/s11252-016-0593-6107. McCarthy, K., and R. G. Lathrop. 2011. Stormwater basins of the New Jersey coastal plain: Subsidies or sinks for frogs and toads? Urban Ecosystems 14: 395-413. https://doi.org/10.1007/s11252-011-0161-z108. McGeoch, M. A., P. C. Le Roux, E. A. Hugo, and S. L. Chown. 2006. Species and 620 community responses to short-term climate manipulation: Microarthropods in the 621 sub-Antarctic. Austral Ecology 31: 719-731109. McGuire, K. L., S. G. Payne, M. I. Palmer, C. M Gillikin, D. Keefe, S. J. Kim, S. M. Gedallovich, J. Discenza, R. Rangamannar, J. A. Koshner, A. L. Massmann, G. Orazi, A. Essene, J. W. Leff, and N. Fierer. 2013. Digging the New York City Skyline: Soil Fungal Communities in Green Roofs and City Parks. PLOS ONE 8. e58020. https://doi.org/10.1371/journal.pone.0058020110. Miller, L. E., A. E. Heim, and J. Lundholm. 2014. Green roof vegetation type affects germination and initial survival of colonizing woody species. Urban Forestry \& Urban Greening 13: 892-899. https://doi.org/10.1016/j.ufug.2014.10.001111. Molineux, C. J., C. H. Fentiman, and A. C. Gange. 2009. Characterising alternative recycled waste materials for use as green roof growing media in the U.K. Ecological Engineering 35: 1507-1513. https://doi.org/10.1016/j.ecoleng.2009.06.010112. Moore, T. L. C., and W. F. Hunt. 2012. Ecosystem service provision by stormwater wetlands and ponds - A means for evaluation? Water Research 46: 6811-6823. https://doi.org/10.1016/j.watres.2011.11.026113. Muller, J. N., S. Loh, L. Braggion, S. Cameron, and J. L Firn. 2014. Diverse urban plantings managed with sufficient resource availability can increase plant productivity and arthropod diversity. Frontiers in Plant Science 5: 517. https://doi.org/10.3389/fpls.2014.00517114. Nagase, A., and N. Dunnett. 2013. Establishment of an annual meadow on extensive green roofs in the UK. Landscape and Urban Planning 112: 50-62. https://doi.org/10.1016/j. landurbplan.2012.12.007115. Nagase, A., and N. Dunnett. 2010. Drought tolerance in different vegetation types for extensive green roofs: Effects of watering and diversity. Landscape and Urban Planning 97: 318-327. https://doi.org/10.1016/j. landurbplan.2010.07.005116. Nagase, A., N. Dunnett, and M. -S. Choi. 2013. Investigation of weed phenology in an establishing semi-extensive green roof. Ecological Engineering 58: 156-164. https://doi.org/10.1016/j.ecoleng.2013.06.007117. Nagase, A., and M. Nomura. 2014. An evaluation of one example of biotope roof in Japan: Plant development and invertebrate colonisation after 8 years. Urban Forestry \& Urban Greening 13: 714-724. https://doi.org/10.1016/j.

ufug.2014.07.004118. Nektarios, P. A., N. Ntoulas, E. Nydrioti, I. Kokkinou, E. -M. Bali, and I. Amountzias. 2015. Drought stress response of Sedum sediforme grown in extensive green roof systems with different substrate types and depths. Scientia Horticulturae 181: 52-61. https://doi.org/10.1016/j.scienta.2014.10.047119. Nicolet, P., J. Biggs, G. Fox, M. J. Hodson, C. Reynolds, M. Whitfield, and P. Williams. 2004. The wetland plant and macroinvertebrate assemblages of temporary ponds in England and Wales. Biological Conservation 120: 261-278. https://doi.org/10.1016/j.biocon.2004.03.010120. Noble, A., and C. Hassall. 2015. Poor ecological quality of urban ponds in northern England: causes and consequences. Urban Ecosystems 18: 649-662. https://doi.org/10.1007/s11252-014-0422-8121. O’Brien, C. D. 2015. Sustainable drainage system (SuDS) ponds in Inverness, UK and the favourable conservation status of amphibians. Urban Ecosystems 18: 321-331. https://doi.org/10.1007/ s11252-014-0397-5122. Parkins, K. L., and J. A. Clark. 2015. Green roofs provide habitat for urban bats. Global Ecology and Conservation 4: 349-357. https://doi.org/10.1016/j.gecco.2015.07.011123. Parris, K. M. 2006. Urban amphibian assemblages as metacommunities. Journal of Animal Ecology 75: 757-764. https://doi.org/10.1111/j.1365-2656.2006.01096.x124. Pearce, H., 
and C. L. Walters. 2012. Do Green Roofs Provide Habitat for Bats in Urban Areas? Acta Chiropterologica 14: 469-478. https:// doi.org/10.3161/150811012X661774125. Perini, K., and P. Rosasco. 2013. Cost-benefit analysis for green façades and living wall systems. Building and Environment 70:110-121. https://doi.org/10.1016/j.buildenv.2013.08.012126. Pétremand, G., Y. Chittaro, S. Braaker, S. Brenneisen, M. Gerner, M. K. Obrist, S. Rochefort, A. Szallies, and M. Moretti. 2018. Ground beetle (Coleoptera: Carabidae) communities on green roofs in Switzerland: synthesis and perspectives. Urban Ecosystems 21: 119-132. https://doi.org/10.1007/s11252-017-0697-7127. Pinel-Alloul, B., and E. -A. Mimouni. 2013. Are cladoceran diversity and community structure linked to spatial heterogeneity in urban landscapes and pond environments? Hydrobiologia 715: $195-212$. https://doi.org/10.1007/s10750-013-1484-y128. Prellwitz, S. G., and A. M. Thompson. 2014. Biota and hydrology influence soil stability in constructed wetlands. Ecological Engineering 64: 360-366. https://doi.org/10.1016/j.ecoleng.2014.01.010129. Qiu, Y., B. J. W. Chen, Y. Song, Z. Y. X. Huang, L. Wan, C. Huang, M. Liu, and C. Xu. 2016. Composition, distribution and habitat effects of vascular plants on the vertical surfaces of an ancient city wall. Urban Ecosystems 19: 939-948. https://doi. org/10.1007/s11252-016-0528-2130. Ruggiero, A., R. Céréghino, J. Figuerola, P. Marty, and S. Angélibert. 2008. Farm ponds make a contribution to the biodiversity of aquatic insects in a French agricultural landscape. Comptes Rendus Biologies 331: 298-308. https://doi.org/10.1016/j.crvi.2008.01.009131. Rumble, H., and A. C. Gange. 2013. Soil microarthropod community dynamics in extensive green roofs. Ecological Engineering 57: 197-204. https://doi.org/10.1016/j.ecoleng.2013.04.012Santoul, F.,

A. Gaujard, S. Angélibert, S. Mastrorillo, and R. Céréghino. 2009. Gravel pits support waterbird diversity in an urban landscape.

Hydrobiologia 634: 107-114. https://doi.org/10.1007/s10750-009-132. Bates, A. J., J. P. Sadler, R. Mackay. 2013. Vegetation development over four years on two green roofs in the UK. Urban Forestry \& Urban Greening 12:98-108. https://doi. org/10.1016/j.ufug.2012.12.0036-6133. Schindler, B. Y., A. B. Griffith, and K. N. Jones. 2011. Factors influencing arthropod diversity on green roofs. Cities and the Environment (CATE) 4(5).134. Schindler, B. Y., L. Blank, S. Levy, G. Kadas, D. Pearlmutter, and L. Blaustein. 2016. Integration of photovoltaic panels and green roofs: review and predictions of effects on electricity production and plant communities. Israel Journal of Ecology \& Evolution 62: 68-73. https://doi.

org/10.1080/15659801.2015.1048617135. Schrader, S., and M. Böning. 2006. Soil formation on green roofs and its contribution to urban biodiversity with emphasis on Collembolans. Pedobiologia 50: 347-356. https://doi.org/10.1016/j.

pedobi.2006.06.003136. Shochat, E., S. B. Lerman, J. M. Anderies, P. S. Warren, S. H. Faeth, and C. H. Nilon. 2010. Invasion, Competition, and Biodiversity Loss in Urban Ecosystems. BioScience 60: 199-208. https://doi.org/10.1525/

bio.2010.60.3.6Shulse, C. D., R. D. Semlitsch, and M. Trauth Kathleen. 2013. Mosquitofish dominate amphibian and invertebrate community development in experimental wetlands. Journal of Applied Ecology 50: 1244-1256. https://doi. org/10.1111/1365-2664.137. Baumann, N. 2006. Ground-Nesting Birds on Green Roofs in Switzerland: Preliminary Observations. Urban Habitats 4 (1): 37-516138. Smucker, N. J., and N. E. Detenbeck. 2014. Meta-Analysis of Lost Ecosystem Attributes in Urban Streams and the Effectiveness of Out-of-Channel Management Practices. Restoration Ecology 22: 741-748. https://doi. org/10.1111/rec.12134139. Sokol, E. R., B. L. Brown, C. C. Carey, B. M. Tornwall, C. M. Swan, and J. E. Barrett. 2015. Linking management to biodiversity in built ponds using metacommunity simulations. Ecological Modelling 296: 36-45. https:// doi.org/10.1016/j.ecolmodel.2014.10.022140. Song, U., E. Kim, J. H. Bang, D. J. Son, B. Waldman, and E. J. Lee. 2013. Wetlands are an effective green roof system. Building and Environment 66: 141-147. https://doi.org/10.1016/j. buildenv.2013.04.024141. Thornhill, I. 2013. Water quality, biodiversity and ecosystem functioning in ponds across an urban land-use gradient in Birmingham, U.K.142. Thornhill, I., L. Batty, R. G. Death, N. R. Friberg, and M. E. Ledger. 2017. Local and landscape scale determinants of macroinvertebrate assemblages and their conservation value in ponds across an urban land-use gradient. Biodiversity and Conservation 26: 1065-1086. https://doi.org/10.1007/s10531-016-1286-4143. Thuring, C., and G. Grant. 2016. The biodiversity of temperate extensive green roofs - a review of research and practice. Israel Journal of Ecology \& Evolution 62: 44-57. https://doi.org/10.1080/15659801.2015.1091190144. Toland, D. C., M. E. Boyer, G. V. McDonald, C. P. West, and B. E. Haggard. 2014. Plants influenced by growing media and compost addition on mock green roofs within the Ozark highlands. Journal of Green Building 9: 130-144. https://doi.org/10.3992/1943-4618-9.1.130145. Toland, D. C., B. E. Haggard, and M. E., Boyer. 2012. Evaluation of Nutrient Concentrations in Runoff Water from Green Roofs, Conventional Roofs, and Urban Streams. Transactions of the ASABE (American Society of Agricultural and Biological Engineers) 55(1): 99-106. https://doi.org/10.13031/2013.41258146. Tonietto, R., J. Fant, J. Ascher, K. Ellis, and D. Larkin. 2011. A comparison of bee communities of Chicago green roofs, parks and prairies. Landscape and Urban Planning 103: 102-108. https://doi.org/10.1016/j.landurbplan.2011.07.004147. Van Mechelen, C., T. Dutoit, and M. Hermy. 2015. Vegetation development on different extensive green roof types in a Mediterranean and temperate maritime climate. Ecological Engineering 82: 571-582. https://doi.org/10.1016/j.ecoleng.2015.05.011148. Vanuytrecht, E., C. Van Mechelen, K. Van Meerbeek, P. Willems, M. Hermy, and D. Raes. 2014. Runoff and vegetation stress of green roofs under different climate change scenarios. Landscape and Urban Planning 122: 68-77. https://doi.org/10.1016/j.landurbplan.2013.11.001149. Vasl, A., and A. Heim. 2016. Preserving plant diversity on extensive green roofs - theory to practice. Israel Journal of Ecology \& Evolution 62: 103-111. https://doi.org/10.1080/15659801.2015.1035507150. Vermonden, K., R. S. E. W. Leuven, G. van der Velde, A. J. Hendriks, M. M. van Katwijk, J. G. M. Roelofs, E. C. H. E. T. Lucassen, O. Pedersen, and K. Sand-Jensen. 2010. Species pool versus site limitations of macrophytes in urban waters. Aquatic Sciences 72: 379-389. https://doi.org/10.1007/ s00027-010-0141-z151. Vermonden, K., R. S. E. W. Leuven, G. van der Velde, M. M. van Katwijk, J. G. M. Roelofs, and A. Jan Hendriks. 2009. Urban drainage systems: An undervalued habitat for aquatic macroinvertebrates. Biological Conservation 142: 1105-1115. https://doi.org/10.1016/j.biocon.2009.01.026152. Vermonden, K., G. van der Velde, and R. S. E. W. Leuven. 2012. Key factors for biodiversity of surface waters in climate proof cities. Resources, Conservation and Recycling 64: 56-62. https:// 
doi.org/10.1016/j.resconrec.2011.01.003153. Vijayaraghavan, K., and F. D. Raja. 2014. Design and development of green roof substrate to improve runoff water quality: Plant growth experiments and adsorption. Water Research 63: 94-101. https://doi. org/10.1016/j.watres.2014.06.012154. Villaseñor, N. R., D. A. Driscoll, P. Gibbons, A. J. K. Calhoun, and D. B. Lindenmayer. 2017. The relative importance of aquatic and terrestrial variables for frogs in an urbanizing landscape: Key insights for sustainable urban development. Landscape and Urban Planning 157: 26-35. https://doi.org/10.1016/j.

landurbplan.2016.06.006155. Wang, J. W., C. H. Poh, C. Y. T. Tan, V. N. Lee, A. Jain, and E. L. Webb. 2017. Building biodiversity: drivers of bird and butterfly diversity on tropical urban roof gardens. Ecosphere 8. e01905-n/a. https://doi. org/10.1002/ecs2.1905156. Washburn, B. E., R. M. Swearingin, C. K. Pullins, and M. E. Rice. 2016. Composition and Diversity of Avian Communities Using a New Urban Habitat: Green Roofs. Environmental Management 57 : 1230-1239. https://doi. org/10.1007/s00267-016-0687-1157. Watts, P. C., J. R. Rouquette, I. J. Saccheri, S. J. Kemp, and D. J. Thompson. 2004. Molecular and ecological evidence for small-scale isolation by distance in an endangered damselfly, Coenagrionmercuriale. Molecular Ecology 13: 2931-2945. https://doi.org/10.1111/j.1365-294X.2004.02300.x158. Williams, N. S. G., J. Lundholm, and J. Scott MacIvor. 2014. FORUM: Do green roofs help urban biodiversity conservation? Journal of Applied Ecology 51:

1643-1649. https://doi.org/10.1111/1365-2664.12333159. Williams, P., M. Whitfield, and J. Biggs. 2010. How can we make new ponds biodiverse? A case study monitored over 7 years. Oertli, B., R. Céréghino, Biggs, Jeremy, S. Declerck, A. Hull, and M. R. Miracle (Eds.), Pond Conservation in Europe. Springer. Netherlands, Dordrecht. pp. 137-148. https://doi.

org/10.1007/978-90-481-9088-1 12160. Wong, G. K. L., and C. Y. Jim. 2016. Do vegetated rooftops attract more mosquitoes? Monitoring disease vector abundance on urban green roofs. Science of The Total Environment 573: 222-232. https://doi. org/10.1016/j.scitotenv.2016.08.102161. Yalcinalp, E., S. Ozveren, A. Meral, M. Pulatkan, and S. Akbulut. 2017. Habitat Effect on Urban Roof Vegetation. Sustainability 9. https://doi.org/10.3390/su9111985 